\title{
Temporally dissociable effects of ketamine on neuronal discharge and gamma oscillations in rat thalamo-cortical networks
}

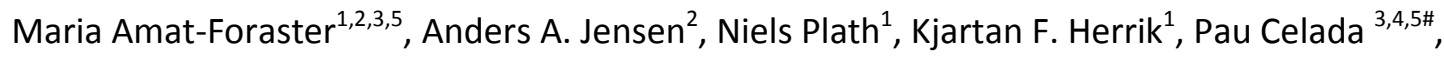 \\ Francesc Artigas ${ }^{3,4,5 \#}$.
}

${ }^{1} \mathrm{H}$. Lundbeck A/S, Synaptic transmission, Valby, Denmark. ${ }^{2}$ University of Copenhagen, Faculty of Health and Medical Sciences, Department of Drug Design and Pharmacology, Copenhagen, Denmark. ${ }^{3}$ Institut d'Investigacions Biomèdiques de Barcelona IIBB-CSIC, Department of Neurochemistry and Neuropharmacology, Barcelona, Spain. ${ }^{4}$ Centro de Investigación Biomédica en Red de Salud Mental, CIBERSAM, Barcelona, Spain. ${ }^{5}$ Institut d'Investigacions Biomèdiques August Pi i Sunyer, IDIBAPS, Barcelona, Spain.

"The last two authors contributed equally to the study.

Short title: Ketamine and thalamo-cortical networks

Corresponding author: Dr. Francesc Artigas and Pau Celada, IIBB-CSIC, CIBERSAM. Department of Neurochemistry and Neuropharmacology, Rosselló $1616^{\text {th }}$ floor, 08036 Barcelona, Spain, Tel: +34 933638315, Fax: +34 933638301, E-mail: francesc.artigas@iibb.csic.es; Pau.celada@iibb.csic.es

Maria Amat-Foraster: maaf@lundbeck.com

Anders A. Jensen: aaj@sund.ku.dk

Niels Plath: niep@lundbeck.com

Kjartan F. Herrik: kfh@lundbeck.com

Pau Celada: pau.celada@iibb.csic.es 


\section{Abstract}

Background: Sub-anesthetic doses of the non-competitive $N$-methyl- $D$-aspartate receptor (NMDAR) antagonist ketamine evoke immediate and persistent antidepressant effects in treatmentresistant depressed patients and antidepressant-like effects in rodents through still poorly understood mechanisms. Since phencyclidine (PCP) disinhibits thalamo-cortical networks by blocking NMDA-Rs on GABAergic neurons of the reticular thalamic nucleus (RtN), we examined ketamine's actions in the same areas.

Methods: Single units and local field potentials were recorded in chloral hydrate anesthetized male Wistar rats. The effects of cumulative ketamine doses $(0.25-5 \mathrm{mg} / \mathrm{kg}$, i.v.) on neuronal discharge and oscillatory activity were examined in RtN, mediodorsal and centromedial (MD/CM) thalamic nuclei, and layer VI of the medial prefrontal cortex (mPFC).

Results: Ketamine (1, 2 and $5 \mathrm{mg} / \mathrm{kg}$, i.v.) significantly decreased the discharge of MD/CM, RtN and layer VI mPFC pyramidal neurons. Simultaneously, ketamine decreased the power of low frequency oscillations in all areas examined and increased gamma oscillations in mPFC and $\mathrm{MD} / \mathrm{CM}$. Lower ketamine doses ( 0.25 and $0.5 \mathrm{mg} / \mathrm{kg}$, i.v.) were ineffective.

Conclusions: As observed for PCP, ketamine markedly inhibited the activity of RtN neurons. However, unlike $P C P$, this effect did not translate into a disinhibition of $M D / C M$ and $\mathrm{mPFC}$ excitatory neurons, possibly due to a more potent and simultaneous blockade of NMDA-Rs by ketamine in $\mathrm{MD} / \mathrm{CM}$ and $\mathrm{mPFC}$ neurons. Hence, in contrast to the presumed excitatory action of ketamine via AMPA-R receptors following NMDA-R blockade, the present in vivo results show an early transient inhibition of neuronal discharge and an increase in gamma oscillations, an effect that may underlie its antidepressant action. 


\title{
Temporally dissociable effects of ketamine on neuronal discharge and gamma oscillations in rat thalamo-cortical networks
}

\author{
Maria Amat-Foraster ${ }^{1,2,3,5}$, Anders A. Jensen ${ }^{2}$, Niels Plath ${ }^{1}$, Kjartan F. Herrik ${ }^{1}$, Pau Celada ${ }^{3,4,5 \#}$, Francesc \\ Artigas $^{3,4,5 \#}$.
}

${ }^{1} \mathrm{H}$. Lundbeck A/S, Synaptic transmission, Valby, Denmark. ${ }^{2}$ University of Copenhagen, Faculty of Health and Medical Sciences, Department of Drug Design and Pharmacology, Copenhagen, Denmark. ${ }^{3}$ Institut d'Investigacions Biomèdiques de Barcelona IIBB-CSIC, Department of Neurochemistry and Neuropharmacology, Barcelona, Spain. ${ }^{4}$ Centro de Investigación Biomédica en Red de Salud Mental, CIBERSAM, Barcelona, Spain. ${ }^{5}$ Institut d'Investigacions Biomèdiques August Pi i Sunyer, IDIBAPS, Barcelona, Spain.

"The last two authors contributed equally to the study.

Short title: Ketamine and thalamo-cortical networks

Corresponding author: Dr. Francesc Artigas and Pau Celada, IIBB-CSIC, CIBERSAM. Department of Neurochemistry and Neuropharmacology, Rosselló $1616^{\text {th }}$ floor, 08036 Barcelona, Spain, Tel: +34 933638315, Fax: +34 933638301, E-mail: francesc.artigas@iibb.csic.es; Pau.celada@iibb.csic.es

Maria Amat-Foraster: maaf@lundbeck.com

Anders A. Jensen: aaj@sund.ku.dk

Niels Plath: niep@lundbeck.com

Kjartan F. Herrik: kfh@lundbeck.com

Pau Celada:pau.celada@iibb.csic.es 


\section{Abbreviations:}

(RM)-ANOVA, (repeated measures) analysis of variance

ACC, anterior cingulate cortex

AMPA-R, $\alpha$-amino-3-hydroxy-5-methyl-4-isoxazolepropionic acid receptors

$\mathrm{AP}$, anterior posterior

$\mathrm{CM}$, centromedial nucleus of the thalamus

FFT, fast Fourier transformation

GABA, gamma-Aminobutyric acid

HNK, (2R,6R)-hydroxynorketamine

IL, infralimbic cortex

i.p., intraperitoneal

i.v., intravenous

Ket, $(\mathrm{R}, \mathrm{S})$-ketamine

L, lateral

LFP, local field potential

MD, mediodorsal nucleus of the thalamus

(m)PFC, (medial) prefrontal cortex

NMDA-R, N-metyl-D-aspartate receptors

norket, $(\mathrm{R}, \mathrm{S})$-norketamine

PCP, phencyclidine

RtN, reticular nucleus of the thalamus

SEM, standard error of means

V, ventral

Veh, vehicle 


\section{Abstract}

Background: Sub-anesthetic doses of the non-competitive $N$-methyl- $D$-aspartate receptor (NMDA-R) antagonist ketamine evoke immediate and persistent antidepressant effects in treatment-resistant depressed patients and antidepressant-like effects in rodents through still poorly understood mechanisms. Since phencyclidine (PCP) disinhibits thalamo-cortical networks by blocking NMDA-Rs on GABAergic neurons of the reticular thalamic nucleus (RtN), we examined ketamine's actions in the same areas.

Methods: Single units and local field potentials were recorded in chloral hydrate anesthetized male Wistar rats. The effects of cumulative ketamine doses $(0.25-5 \mathrm{mg} / \mathrm{kg}$, i.v.) on neuronal discharge and oscillatory activity were examined in RtN, mediodorsal and centromedial (MD/CM) thalamic nuclei, and layer VI of the medial prefrontal cortex (mPFC).

Results: Ketamine (1, 2 and $5 \mathrm{mg} / \mathrm{kg}$, i.v.) significantly decreased the discharge of MD/CM, RtN and layer VI MPFC pyramidal neurons. Simultaneously, ketamine decreased the power of low frequency oscillations in all areas examined and increased gamma oscillations in mPFC and MD/CM. Lower ketamine doses $(0.25$ and $0.5 \mathrm{mg} / \mathrm{kg}$, i.v.) were ineffective.

Conclusions: As observed for PCP, ketamine markedly inhibited the activity of RtN neurons. However, unlike $P C P$, this effect did not translate into a disinhibition of $M D / C M$ and $\mathrm{mPFC}$ excitatory neurons, possibly due to a more potent and simultaneous blockade of NMDA-Rs by ketamine in MD/CM and mPFC neurons. Hence, in contrast to the presumed excitatory action of ketamine via AMPA-R receptors following NMDA-R blockade, the present in vivo results show an early transient inhibition of neuronal discharge and an increase in gamma oscillations, an effect that may underlie its antidepressant action.

Key words: NMDA receptor antagonists; ketamine; thalamo-cortical networks; neuronal oscillations; single unit recordings; local field potentials.

Highlights:

- $\quad$ PCP and ketamine differentially affect thalamo-cortical activity anesthetized in rats

- As phencyclidine, ketamine inhibits GABA neurons of the reticular thalamic nucleus

- Unlike phencyclidine, ketamine does not excite $\mathrm{MD} / \mathrm{CM}$ nuclei excitatory neurons

- Ketamine also inhibits layer VI pyramidal neurons in medial prefrontal cortex

- In parallel, ketamine enhances gamma band power and reduces delta band power 


\section{Introduction}

Major depressive disorder (MDD) is a severe psychiatric disorder with a high prevalence and socioeconomic impact worldwide (Kassebaum et al.; Kessler et al., 2003; Murray et al., 2012). Current monoaminergic antidepressants show slow onset of antidepressant action and limited efficacy (Penn and Tracy, 2012; Rush et al., 2006; Stahl, 2000; Trivedi et al., 2006). Therefore, there is an urgent need to develop faster and more effective treatments.

A substantial amount of evidence implicates the glutamatergic system in the pathophysiology and treatment of mood disorders (Beneyto et al., 2007; Feyissa et al., 2009; Hasler et al., 2007; Sanacora, 2009; Sanacora et al., 2012; Skolnick et al., 1996). Functional NMDA-R antagonists exhibit antidepressant-like effects in rodents (Skolnick et al., 2009), and, sub-anesthetic doses of the noncompetitive NMDA-R antagonist ketamine has been shown to evoke immediate and persistent antidepressant responses in treatment-resistant depressed patients and antidepressant-like effects in rodents (Browne and Lucki, 2013; Mion and Villevieille, 2013; Monteggia and Zarate, 2015; Newport et al., 2015; Singh et al., 2016; Zarate et al., 2006). However, since ketamine treatment is limited by its psychotomimetic properties and abuse potential (Sanacora et al., 2017), there is a need to understand the mechanism(s) underlying its antidepressant action, ultimately leading to the development of more effective antidepressant drugs devoid of ketamine's side effects.

Non-competitive NMDA-R antagonists may preferentially block NMDA-Rs in GABAergic neurons thereby enhancing excitatory neurotransmission and glutamate release (Homayoun and Moghaddam, 2007; Jackson et al., 2004; Kargieman et al., 2007; Moghaddam et al., 1997). Ketamine's action appears to involve activation of $\alpha$-amino-3-hydroxy-5-methyl-4-isoxazolepropionate receptors (AMPA-Rs) (Autry et al., 2011; Fukumoto et al., 2016; Koike and Chaki, 2014; Li et al., 2010; Maeng et al., 2008; Zanos et al., 2016), that subsequently may evoke biochemical/structural changes, increasing mTOR signaling and synaptogenesis (Duman and Aghajanian, 2012; Li et al., 2010; Popp et al., 2016). This might explain the long-lasting effects of ketamine that outlast the actual drug exposure (Mion and Villevieille, 2013).

The ventral anterior cingulate cortex in humans or its homologous region in rodents, the infralimbic (IL) subdivision of the medial prefrontal cortex (mPFC), is a sensitive area for the ketaminemediated effects (Downey et al., 2016; Fuchikami et al., 2015; Li et al., 2016). Likewise, AMPA-R stimulation in IL evokes antidepressant-like effects in rats (Gasull-Camos et al., 2017). Given the reciprocal connectivity between the PFC and many subcortical brain areas (Gabbott et al., 2005; Groenewegen and Uylings, 2000), it is still unclear whether the actions of NMDA-R antagonists on PFC activity are locally or distally mediated. 
Among the latter areas, several thalamic nuclei, in particular the mediodorsal nucleus (MD), make up the most important subcortical glutamate source to the PFC (Groenewegen and Uylings, 2000; Kuroda et al., 1998). In support of this, electrical stimulation of MD evokes AMPA-R- and NMDA-Rmediated responses in mPFC pyramidal neurons (Pirot et al., 1995). Interestingly, the selective chemogenetic activation of the MD inputs to the MPFC is sufficient to elicit antidepressant-like effects (Miller et al., 2017). Moreover, neuroimaging studies have shown that ketamine affects thalamic function (Downey et al., 2016; Maltbie et al., 2016; Vollenweider and Kometer, 2010). Collectively, these observations suggest an involvement of thalamo-cortical pathways in the action of ketamine, as previously observed for phencyclidine (PCP), another non-competitive NMDA-R antagonist. PCP has also been shown to elicit weak antidepressant-like effects in one rodent study (Hillhouse et al., 2014). In anesthetized rats, PCP inhibits GABAergic neurons from the reticular nucleus of the thalamus (RtN) (Troyano-Rodriguez et al., 2014), which tonically inhibits the rest of the thalamic nuclei. This effect results in the activation of a large percentage of thalamic neurons in the MD and centromedial (CM) nuclei and of mPFC pyramidal neurons (albeit a smaller percentage are inhibited by PCP), leading to increased c-fos expression in many cortical and thalamic areas (Kargieman et al., 2007; Santana et al., 2011).

In the present study we have investigated the actions of ketamine on thalamo-cortical networks using in vivo electrophysiology in anesthetized rats to increase knowledge of the brain circuitry affected by ketamine and to elucidate the mechanism(s) underlying its antidepressant effects. We have used the same experimental conditions and setting as previous electrophysiological studies from this laboratory on PCP (see above), which allows a direct comparison of the effects of both NMDA-R antagonists. 


\section{Methods and Materials}

2.1. Animals. Animal care followed EU regulations (directive $2010 / 63$ of 22 September 2010) and was approved by the Institutional Animal Care and Use Committee. Male albino Wistar rats (Charles River; 250-350 g) were kept under standard temperature $\left(22 \pm 1.5^{\circ} \mathrm{C}\right)$ and humidity $(55-65 \%)$ controlled laboratory conditions with food and water ad libitum in a $12 \mathrm{~h}: 12 \mathrm{~h}$ light/ dark cycle.

2.2. Drugs. (R,S)-Ketamine (Ketolar $50 \mathrm{mg} / \mathrm{ml}$, Pfizer) was dissolved in $0.9 \%$ saline $(0.5 \mathrm{mg} / \mathrm{ml}$ ) and administered at cumulative doses of $0.25,0.5,1,2$ and $5 \mathrm{mg} / \mathrm{kg}$, chosen based on the pharmacokinetic profile of ketamine to achieve brain exposures in rats comparable to the clinical concentrations (Shaffer et al., 2014). All drugs and vehicles (veh) were administered intravenously (i.v.) through a femoral vein cannula in chloral hydrate anesthetized rats. The following dosing paradigms were used (injection every $5 \mathrm{~min}$ ): veh/veh1/veh2/veh3, veh/Ket0.25/Ket0.5 and veh/Ket1/Ket2/Ket5 ( $\mathrm{n}=5-15$ per group, Supplementary Table 1).

2.3. Surgical procedure. Rats were anesthetized with chloral hydrate $(450 \mathrm{mg} / \mathrm{kg}$, i.p. followed by $50-70$ $\mathrm{mg} / \mathrm{kg}$ per h i.p. using a perfusion pump and supplemented by $0.2 \mathrm{ml}$ i.v. injection if required). A femoral vein cannula (P20 tubing) was inserted, and the rats were placed in a stereotaxic frame (David Kopf, Tujunga, CA) and kept at $37{ }^{\circ} \mathrm{C}$ via a heating pad (Cibertec RTC1, Madrid, Spain). One small hole was drilled into the skull to accommodate a glass electrode in either the RtN, the MD/CM or layer VI of the mPFC (coordinates relative to bregma (Paxinos and Watson, 2007) RTN: AP (anterior posterior): -1.4 to $3.14 \mathrm{~mm}, \mathrm{~L}$ (lateral): -1.8 to $-3,8 \mathrm{~mm}, \mathrm{~V}$ (ventral): -5 to $-6.5 \mathrm{~mm}$; MD/CM: AP: $-2,5 \mathrm{~mm}$, L: -0.6 to -0.8 $\mathrm{mm}, \mathrm{V}:-4.7$ to $-6.2 \mathrm{~mm}$; mPFC: AP: +3.1 to $+3.4 \mathrm{~mm}, \mathrm{~L}:-0.6$ to $-1 \mathrm{~mm}, \mathrm{~V}:-1.4$ to $-4.4 \mathrm{~mm}$ ). Additionally, in the mPFC recordings, a metal electrode was inserted in the infralimbic cortex (IL) (AP: $+3.2 \mathrm{~mm}, \mathrm{~L}$ : $+0.7 \mathrm{~mm}, \mathrm{~V}:-4.2 \mathrm{~mm}$ ) and a stimulating electrode was also placed in the MD (AP: $-2.5 \mathrm{~mm}, \mathrm{~L}:-0.6 \mathrm{~mm}$, $\mathrm{V}:-5.2 \mathrm{~mm}$ ). A 2-mm screw was fixed in the skull to act as a reference/ground with a platinum wire.

2.4. Electrophysiological recordings. Single unit and local field potential (LFP) recordings in the RtN, $\mathrm{MD} / \mathrm{CM}$ and layer $\mathrm{VI}$ of the mPFC were performed as previously described (Kargieman et al., 2007; Santana et al., 2011; Troyano-Rodriguez et al., 2014). Additional LFPs were recorded in the contralateral IL simultaneously with single unit and LFP recordings with glass electrodes using unipolar stainless steel 
electrodes (single unit band-pass filter: $30 \mathrm{~Hz}-10 \mathrm{kHz}$; LFPs band-pass filter of $0.1-100 \mathrm{~Hz}$ in RtN and $\mathrm{MD} / \mathrm{CM}$ and $0.1-200 \mathrm{~Hz}$ in $\mathrm{mPFC}$ ).

All recorded units in the MPFC were identified as cortico-thalamic neurons by antidromic activation from the MD (electrical stimulation of the MD: square-wave pulses -0.5 ms duration, 250-500 $\mu \mathrm{A}$ intensity- delivered at frequencies of 3-10 Hz) using a bipolar concentric tungsten electrode (TM53CCINS, World Precision Instruments Inc., USA) on basis of their fixed latency and collision with a spontaneous spike as described in a previous study (latency: 18.5 $\pm 3.4 \mathrm{~ms}, \mathrm{n}=29$ ) (Pirot et al., 1994). A scheme of the recording areas, their reciprocal connectivity and representative examples of single unit recordings is given in Figure 1.

2.5. Data analysis. To assess the acute effects of ketamine at different doses, each treatment was recorded for $5 \mathrm{~min}$, of which the last 2 min periods were averaged and normalized to a stable $5 \mathrm{~min}$ baseline for the firing rate (Figures $2 \mathrm{~A}, 3 \mathrm{~A}, 4 \mathrm{~A}$ ) and to the last 1 min baseline for the oscillatory activity (Figures 2B, 3C, 4B). Similarly, to visualize prolonged effects of the higher dose administrated, the last 2 min period per $5 \mathrm{~min}$ bins were averaged and normalized to a stable $5 \mathrm{~min}$ baseline for the firing rate (Figure 3B) and to the last $1 \mathrm{~min}$ baseline for the oscillatory activity (Figures 3D-E, 4C-D). Analysis of single unit recordings was carried out importing the signals to MATLAB (MathWorks, Natick, Massachusetts) for off-line analysis. A burst episode was defined as the occurrence of two or more spikes with an interspike interval of $\leq 4 \mathrm{~ms}$ for the MD, $\leq 10 \mathrm{~ms}$ for the RtN and $<45 \mathrm{~ms}$ for the mPFC (Kargieman et al., 2007; Laviolette et al., 2005; Santana et al., 2011; Sittig and Davidowa, 2001; TroyanoRodriguez et al., 2014; Ushimaru et al., 2012). LFP recordings were Fast Fourier transformed to yield the power of oscillatory activity of $1 \mathrm{~min}$ signal intervals (Spike 2 software version 7.10, Cambridge Electronic Design Limited, UK). LFP signals were divided into 5 main frequency bands of oscillations: delta $0.15-4$, theta $4-8 \mathrm{~Hz}$, alpha $8-12 \mathrm{~Hz}$, beta $12-30 \mathrm{~Hz}$, gamma $30-90 \mathrm{~Hz}$ or low gamma $30-48 \mathrm{~Hz}$. Data from 48 to $52 \mathrm{~Hz}$ and 58 to $62 \mathrm{~Hz}$ frequency range was discarded due to electric noise. One way repeated measures analysis of variance (RM-ANOVA) as between-subject factor and treatment or time as within-subject factor followed by Holm-Sidak post-hoc test were used to assess the differences between baseline and post-injection values of firing rate and power of the oscillations within the same treatment group (Sigma Plot, version 11.0). Data are presented as mean \pm standard error of the means (S.E.M.) with a $p$ value of $<0.05$ being considered significant. 
2.6 Tissue and plasma collection. Plasma and brain concentrations of $(R, S)$-ketamine, $(R, S)$-norketamine and $(2 R, 6 R)$-hydroxynorketamine (HNK) were measured in some animals at the end of the recordings (indicated in Supplementary Figure 4), either $7 \mathrm{~min}$ or $45 \mathrm{~min}$ after the last compound administration. At the terminal time-point, a blood sample was taken by heart puncture and kept in $1.6 \mathrm{mg} \mathrm{EDTA} / \mathrm{mL}$ of blood. Brains were stored at $-80^{\circ} \mathrm{C}$ until they were sectioned at $40 \mu \mathrm{m}$ in serial coronal slices that were stained with neutral red to inspect the electrode placement. Blood samples were centrifuged for $10 \mathrm{~min}$ at $5000 \mathrm{~g}$ at $4{ }^{\circ} \mathrm{C}$ and plasma was stored at $-80^{\circ} \mathrm{C}$ until analysis.

2.7. Quantitative bioanalysis. Rat plasma and brain concentrations of ketamine, norketamine and HNK were determined using ultra performance liquid chromatography coupled to tandem mass spectrometry (MS/MS). Plasma and brain concentrations of the compounds were analyzed by unpaired student t-test using SigmaPlot (version 11.0). 


\section{Results}

\subsection{Firing patterns of reticular, thalamic and cortical neurons.}

The mean firing rates of the recorded neurons during 5 min baseline were: $11.9 \pm 2.3$ spikes/s in the RtN $(n=18), 1.5 \pm 0.3$ spikes/s in the MD/CM $(n=23)$ and $1.5 \pm 0.4$ in the mPFC $(n=29)$. In the RtN, most neurons discharged in burst firing mode. In the $\mathrm{MD} / \mathrm{CM}$, both depolarized and hyperpolarized action potentials were found. Burst episodes were characterized by doublets and triplets. Antidromicallydriven cortico-thalamic pyramidal neurons exhibited a broad pattern of spontaneous activity but most units exhibited irregularly spaced bursts. These firing characteristics are consistent with those observed in previous studies (Pirot et al., 1994; Santana et al., 2011; Troyano-Rodriguez et al., 2014). Representative examples of the firing patterns are given in Figure 1 together with a schematic representation of the projections in the thalamo-cortical network. Systemic administration of vehicle did not significantly affect the firing rate or oscillatory activity in the RtN, MD/CM or mPFC (Supplementary Figure 1).

\subsection{Effects of ketamine on the activity of RtN.}

The effect of ketamine on the discharge of RtN neurons was studied in 13 rats at cumulative doses of 1, 2 and $5 \mathrm{mg} / \mathrm{kg}$ (one neuron per rat). One more rat was added for the analysis of the oscillatory activity $(n=14)$. Ketamine significantly reduced the firing activity of RtN neurons to $61 \%, 65 \%$ and $37 \%$ of baseline at 1,2 and $5 \mathrm{mg} / \mathrm{kg}$, respectively $\left(\mathrm{F}_{4,47}=13.16, \mathrm{p}<0.001, \mathrm{n}=12-13\right)$ (Figure 2A). Ketamine also significantly decreased the number of burst episodes but did not alter the burst pattern of these neurons (Supplementary Table 2A).

In parallel with the effects on neuronal discharge, ketamine dose-dependently decreased delta $(0.15-4 \mathrm{~Hz})$ power to $79 \%, 71 \%$ and $48 \%$ of baseline, at 1,2 and $5 \mathrm{mg} / \mathrm{kg}$, respectively $\left(\mathrm{F}\left[_{4,52}=23.46\right.\right.$, $p<0.001, n=14$ ), whereas the power of other frequency bands remained unaltered (Figures $2 B, 2 C$ ).

\subsection{Effects of ketamine on the activity of $\mathrm{MD} / \mathrm{CM}$.}

The effect of ketamine on MD/CM activity was studied in 5 rats at 0.25 and $0.5 \mathrm{mg} / \mathrm{kg}$ (cumulative doses) and in 12 rats at 1,2 and $5 \mathrm{mg} / \mathrm{kg}$ (cumulative doses; one neuron per rat). Analysis of the oscillatory activity was carried out in the same 12 rats and in one additional rat $(n=13)$. In some rats $(n=6)$, recordings were maintained up to $30 \mathrm{~min}$ after injection of the last dose in order to explore the potentially prolonged effects of the drug. 
Ketamine did not significantly affect $M D / C M$ activity at 0.25 and $0.5 \mathrm{mg} / \mathrm{kg} \quad(\mathrm{n}=5)$ (Supplementary Figures 2, A1-A2). However, ketamine dose-dependently reduced the firing activity of $\mathrm{MD} / \mathrm{CM}$ neurons to $66 \%, 60 \%$ and $37 \%$ of the baseline at 1,2 and $5 \mathrm{mg} / \mathrm{kg}$, respectively $\left(\mathrm{F}_{4,42}=22.79\right.$, $p<0.001, n=11-12$ ) (Figure $3 A)$. In the units examined for $30 \mathrm{~min}(n=6)$, the firing rate returned to baseline approximately 15 min after administration, consistent with the rapid pharmacokinetics of the drug $\left(F[\text { treatment }]_{4,20}=15.84, p<0.001, n=6\right)$ (Figure $3 B$ ). Ketamine $(1,2,5 \mathrm{mg} / \mathrm{kg}$, i.v.) significantly decreased the number of burst episodes, the number of spikes per burst and the burst duration (Supplementary Table 2B).

In parallel, ketamine significantly increased low gamma $(30-48 \mathrm{~Hz})$ power to $137 \%, 140 \%$ and $138 \%$ of the baseline at 1,2 and $5 \mathrm{mg} / \mathrm{kg}$, respectively $\left(F_{4,47}=17.30, p<0.001, n=13\right)$ (Figure $3 C$ ). This effect was sustained for up to 15 min post-administration of the last dose $\left(F_{7,34}=3.70, p<0.01, n=6\right)$ (Figures 3D, 3E). In contrast, ketamine ( $5 \mathrm{mg} / \mathrm{kg}$, i.v.) evoked a significant and transient decrease of delta power to $73 \%$ of the baseline $\left(F_{4,47}=5.70, p<0.001, n=13\right)$ (Figures $\left.3 C-3 E\right)$.

\subsection{Effects of ketamine on the activity of layer VI pyramidal neurons in mPFC}

The effect of ketamine on the discharge of cortico-thalamic neurons was studied in 5 rats at the dose of $0.25 \mathrm{mg} / \mathrm{kg}$ and in 15 rats at the cumulative doses of 1,2 and $5 \mathrm{mg} / \mathrm{kg}$ (one neuron per rat). Oscillatory activity was additionally recorded with a metal electrode placed in the layer VI of the infralimbic cortex in the contralateral hemisphere. Analysis of the oscillatory activity in the $0.25 \mathrm{mg} / \mathrm{kg}$ group was done in the same 5 rats, and the effect was explored up to 40 min post-administration. In the 1,2 and $5 \mathrm{mg} / \mathrm{kg}$ group, the analysis was carried out in 14 rats, and in 12 of them, the recordings could be maintained for up to $30 \mathrm{~min}$ after the last drug administration in order to explore prolonged effects of ketamine.

As in $\mathrm{MD} / \mathrm{CM}$, the low ketamine dose $(0.25 \mathrm{mg} / \mathrm{kg}$, i.v.) did not significantly affect layer VI mPFC activity ( $n=5)$ (Supplementary Figures 2 B1 and B2), while it dose-dependently reduced the firing rate to $74 \%, 53 \%$ and $19 \%$ of the baseline at 1,2 and $5 \mathrm{mg} / \mathrm{kg}$, respectively ( $F[\text { treatment }]_{4,53}=8.10, p<0.001$, $n=13-15$ ) (Figure $4 A$ ). As in $M D / C M$, the firing rate returned to baseline approximately 15 min after administration (Supplementary Table 2C). Ketamine also decreased the number of burst episodes but did not alter the burst pattern of the recorded neurons (Supplementary Table 2C).

Ketamine evoked a transient and significant decrease of delta power $(0.15-4 \mathrm{~Hz})$ to $89 \%, 85 \%$ and $68 \%$ at 1,2 and $5 \mathrm{mg} / \mathrm{kg}$, respectively $\left(\mathrm{F}_{4,52}\right.$ [treatment] $\left.=7.70, \mathrm{p}<0.001, \mathrm{n}=14\right)$ (Figure $\left.4 \mathrm{~B}\right)$. Figures $4 \mathrm{C}$ $4 D$ show the temporal course of ketamine's effect $\left(F_{7,77}[\right.$ treatment] $=5.18, p<0.001, n=12)$. 
In parallel, ketamine (1, 2 and $5 \mathrm{mg} / \mathrm{kg}$, i.v.) significantly increased beta and gamma powers (12$30 \mathrm{~Hz} ; 30-90 \mathrm{~Hz}$, respectively) to $123 \%, 129 \%, 120 \%$ and $135 \%, 137 \%, 115 \%$ of the baseline, respectively (beta: $F[\text { treatment }]_{4,52}=6.21, p<0.001$; gamma: $F[\text { treatment }]_{4,52}=7.46, p<0.001, n=14$ ) (Figure 4B). Unlike for delta power, ketamine evoked a prolonged increase in beta and gamma powers that persisted for up to $30 \mathrm{~min}$ post-administration (beta: $F_{7,77}\left[\right.$ treatment] $=8.07, p<0.001$; gamma $F_{7,77}$ [treatment]=9.92, $\mathrm{n}=12$ ) (Figures 4C, 4D). Similar changes on oscillatory activity were observed with glass electrode recordings (Supplementary Figure 3).

\subsection{Terminal plasma and brain concentrations of ketamine and its metabolites}

Plasma and brain concentrations of ketamine and its major metabolites, norketamine and HNK (Desta et al., 2012) were determined in a subgroup of animals at the end of the recordings. The concentrations of ketamine, norketamine and HNK in plasma and brain 7 and 45 min after the last cumulative dose of 5 $\mathrm{mg} / \mathrm{kg}$ i.v. are given in Supplementary Figure 4. Ketamine concentrations in plasma and brain at 45 min were lower than at 7 min post-administration ( $p<0.01$, unpaired student's t-test) (Supplementary Figure 4). In contrast, HNK concentrations in plasma and brain at 45 min post-administration were significantly higher than at $7 \mathrm{~min}$ post-administration $(p<0.01$, unpaired student's t-test). Norketamine concentrations in plasma and brain were not significantly different at the two different sampling times (n.s., unpaired student's t-test) (Supplementary Figure 4). In brain, the main components at 7 min postadministration were ketamine and HNK (mean ketamine/HNK ratio: 2.9) whereas at 45 min, both compounds were found at comparable concentrations (mean ketamine/HNK ratio: 0.9) (Supplementary Figure 4B). 


\section{Discussion}

In the present study we show that ketamine inhibits the firing activity of thalamo-cortical networks in anesthetized rats. Ketamine dose-dependently decreased the discharge of both excitatory MD/CM relay neurons projecting to PFC as well as laver VI cortico-thalamic pyramidal neurons, despite that ketamine markedly suppressed the discharge of RtN GABAergic neurons known to exert tonic inhibition of the rest of the thalamus. In parallel, ketamine affected population activity in these areas, thus evoking a shortlasting decrease of low frequency oscillations and a more prolonged increase of gamma oscillations in $\mathrm{MD} / \mathrm{CM}$ and PFC. Except in the RtN, the effects of ketamine were strikingly opposite of those evoked by PCP, which activates thalamo-cortical networks (Kargieman et al., 2007; Santana et al., 2011; TroyanoRodriguez et al., 2014). The data from these PCP studies and the present ketamine study are directly comparable since they were conducted with the same experimental conditions in the same setting (see Supplementary Table 3). Likewise, we used doses of both compounds which were comparable in terms of NMDA-R antagonism (Anis, 1983). Importantly, the brain concentrations determined for ketamine in this study were within the range reported in clinical and preclinical studies reporting antidepressant effects (Li et al., 2011; Shaffer et al., 2014), supporting the relevance of these findings for the antidepressant action of ketamine.

\subsection{Acute effect of ketamine on the activity of thalamo-cortical networks.}

As observed with PCP (Troyano-Rodriguez et al., 2014) and in agreement with the hyperpolarization of RtN neurons mediated by the NMDA-R antagonist APV in vitro (Zhang et al., 2009), ketamine markedly inhibited the activity of GABAergic RtN neurons. However, in contrast to PCP (Santana et al., 2011), this effect did not translate into an increased activity of $\mathrm{MD} / \mathrm{CM}$ neurons. Instead, ketamine acutely attenuated the discharge of excitatory $\mathrm{MD} / \mathrm{CM}$ neurons that mainly project to layers III and $\mathrm{V}-\mathrm{VI}$ of the PFC (Kuroda et al., 1998) and of cortico-thalamic neurons in layer VI of mPFC. Similarly, MK-801 evoked an overall decrease of spiking activity in the mPFC of urethane-anesthetized rats (Kiss et al., 2011)

Most cortical pyramidal and thalamic relay neurons express NMDA-Rs (Monyer et al., 1994; Wenzel et al., 1997). Therefore, the reduction in firing rate induced by ketamine in these areas is likely to result from a direct blockade of NMDA-Rs in the recorded neurons. In contrast, previous observations in PFC and MD/CM indicate that PCP in anesthetized and MK-801 in awake rats, preferentially increase excitatory neuron discharge after the blockade of NMDA-Rs on local or distal GABAergic elements (Homayoun and Moghaddam, 2007; Jackson et al., 2004; Jodo et al., 2003; Kargieman et al., 2007; Santana et al., 2011; Troyano-Rodriguez et al., 2014). In the latter studies, inhibitory actions of PCP were 
actually also observed in MPFC and MD/CM, yet in a lower percentage of neurons than that of excited neurons, thus resulting in an overall increase of discharge (Supplementary Table 3). These differences suggest that the net effect of any given NMDA-R antagonist on thalamo-cortical neurons is determined by the balance between the inhibitory effect induced by its NMDA-R blockade in the recorded unit and the disinhibition evoked by NMDA-Rs located on GABAergic elements controlling thalamic and cortical activity (e.g., GABA interneurons in PFC, RtN and basal ganglia structures controlling the activity of excitatory thalamic nuclei). Given that ketamine and PCP inhibit RtN neurons to a similar extent, their differential effect in MD/CM and MPFC is possibly due to a more potent and simultaneous blockade of NMDA-Rs by ketamine in MD/CM and PFC, which occludes the disinhibition produced by the reduction of RtN activity (see scheme in Figure 5).

Several mechanisms could underlie this difference between PCP and ketamine. Although ketamine, MK-801 and PCP essentially are non-selective antagonists of the different GluN1/2 NMDA-R subtypes (Dravid et al., 2007; Yamakura et al., 1993), ketamine exhibits some preference for recombinant GluN2C- and 2D-containing receptors over the other GluN1/2 subtypes in presence of $\mathrm{Mg}^{2+}$ (Khlestova et al., 2016; Kotermanski and Johnson, 2009). Given the preferential expression of the GluN2C subunits in thalamus (Karavanova et al., 2007; Monyer et al., 1994; Wenzel et al., 1997) this might partly explain a preferential NMDA-R blockade by ketamine in the excitatory thalamic nuclei, thus counteracting the disinhibition induced by NMDA-R blockade in RtN and the subsequent reduction of GABA inputs onto MD/CM neurons. The actions of both ketamine and PCP are voltage-dependent, with ketamine exhibiting a higher voltage-dependency than PCP (Davies et al., 1988; Gilling et al., 2009; MacDonald et al., 1991). This suggests that PCP and ketamine may exert differential actions on the recorded neurons, depending on their depolarization state. Likewise, despite both agents were used at subanesthetic doses, a differential effect of PCP and ketamine on chloral hydrate-induced anesthesia may also contribute. Indeed, anesthesia is known to impact on the excitatory/inhibitory balance of these neurons. Hence, RtN neurons are more hyperpolarized under anesthesia (Pinault, 2004; Yen and Shaw, 2003) while they are depolarized in awake animals. Indeed, the main limitation of this one and previous studies is the use of anesthesia, which warrants further investigation of the effects of these two agents on neuronal activity in freely-moving rats.

In agreement with the present observations, ketamine has previously been reported to reduce metabolic activity in thalamic nuclei of mice, including RtN and MD, in parallel with an increased activity of upper cortical layers (I-III) of the mPFC (Dawson et al., 2014; Dawson et al., 2013). However neuroimaging studies in healthy volunteers and depressed patients as well as in non-human primates 
have reported that ketamine increases glucose metabolism in the cingulate cortex and the thalamus (De Simoni et al., 2013; Downey et al., 2016; Doyle et al., 2013; Maltbie et al., 2016; Vollenweider and Kometer, 2010). These discrepancies are not fully understood and may involve several factors, including i) species differences, perhaps related to the presence of thalamic interneurons in primate and human brains, but not in rodent brain, except for the lateral geniculate nucleus (Arcelli et al., 1997; Ohara et al., 1983), ii) differential target selectivity of ketamine at the very different doses and routes used in these

studies, iiii) variable concentrations of ketamine and metabolites at the different time points reported in the above studies [This point may be particularly relevant, given the putative involvement of $(2 \mathrm{~S}, 6 \mathrm{~S} ; 2 \mathrm{R}, 6 \mathrm{R})-\mathrm{HNK}$ metabolite in the antidepressant effects of ketamine (Zanos et al., 2016)], iv) the use of anesthesia in some studies, since ketamine increases glucose metabolism in awake but not in anesthetized rodents, and most preclinical fMRI studies are conducted in anesthetized animals (Littlewood et al., 2006), and v) differential effects depending on the administration route and rate of infusion.

Together with the decrease in neuronal discharge, ketamine transiently decreased delta (0.15-4 $\mathrm{Hz}$ ) power in the RTN, MD/CM and mPFC (IL cortex). Similarly, PCP acutely decreased delta oscillations in anesthetized rats (Kargieman et al., 2007; Neal and Bond, 1985; Santana et al., 2011; Troyano-Rodriguez et al., 2014). Delta oscillations reflect synchronized activity changes of neuronal networks and are generated by neocortical and thalamo-cortical networks (Steriade et al., 1993; Timofeev and Chauvette, 2011). Interestingly, the acute reductions in delta power mediated by ketamine are short-lasting, reflecting its fast pharmacokinetics. The association of this effect to its psychotomimetic activity is supported by the short-lasting perceptual disturbances induced by i.v. ketamine in clinical studies (Zarate et al., 2006). Likewise, the reduction in delta power induced by PCP following its i.v. administration is reversed by marketed and experimental antipsychotic drugs (Kargieman et al., 2007; Llado-Pelfort et al., 2016; Santana et al., 2011; Troyano-Rodriguez et al., 2014).

\subsection{Prolonged effect of ketamine on thalamo-cortical activity}

The increase in gamma oscillations in $\mathrm{MPFC}$ and MD/CM nuclei mediated by ketamine were characterized by a distinct temporal pattern compared to its reduction of delta oscillations as this increase was observed throughout the recording period and long after delta oscillations had returned to baseline values. Given the likely association of the latter parameter to ketamine's psychotomimetic effects, the persisting increase in gamma power may possibly be associated with ketamine's antidepressant effects as these occur after the psychotomimetic phase of the drug. 
NMDA-R antagonists also increase gamma power in the cortex of anesthetized and freely moving animals (Hakami et al., 2009; Hiyoshi et al., 2014; Kittelberger et al., 2012; Phillips et al., 2012; Pinault, 2008; Sanacora et al., 2014; Wood et al., 2012; Zanos et al., 2016), which suggests that the anesthetized preparation as predictive of effects in freely-moving rodents, without the potential confounding effects of behavioral activity in awake animals. Gamma oscillations reflect local cell assembly organization in cortical networks. They depend on the activation of ionotropic excitatory receptors and are therefore considered to reflect neuronal excitation/disinhibition (Buzsaki and Draguhn, 2004; Cunningham et al., 2003; Whittington et al., 2000). Therefore, the ketamine-induced increase of gamma oscillations in mPFC may be taken as a surrogate measure of an increase in PFC (in particular, IL) excitability. Since the present single unit data enables to discard an increased excitatory thalamic input as a potential source of this effect, this suggests an involvement of other cortical or subcortical excitatory inputs. Among the former inputs, blockade of NMDA-Rs in fast-spiking GABAergic interneurons may be involved in gamma generation in cortical networks (Cardin et al., 2009; Carlen et al., 2012) and excitation of cortical pyramidal neurons (Hanson et al., 2013; Homayoun and Moghaddam, 2007; Jackson et al., 2004; Quirk et al., 2009). However, both effects are unlikely to occur in layer VI, at least in the short run, given the inhibitory effect of ketamine in cortico-thalamic pyramidal neurons. However, by virtue of the differential connectivity of pyramidal neurons in middle and deep mPFC layers in the various subfields (Gabbott et al., 2005), we cannot rule out a ketamine action on other PFC layers. A further in-depth analysis of this effect is certainly warranted, given its potential association with ketamine's antidepressant effects.

The temporal dissociation between the effect of ketamine on delta and gamma oscillations (with more persistent effects on the latter) is reminiscent of the i.v. effects of ketamine in patients, with a persistent antidepressant effect by the end of the psychotomimetic phase (Zarate et al., 2006) that follows the rapid pharmacokinetics of ketamine (Mion and Villevieille, 2013). HNK has been suggested to mediate the delayed antidepressant effect through the activation of AMPA-Rs (Zanos et al., 2016) although a very recent study indicates that HNK also blocks synaptic NMDA-R function, as observed for the parent compound (Suzuki et al., 2017). Interestingly, the present data show that the increase in gamma power occurs after a switch in the relative concentration of ketamine and its metabolites with the HNK/ketamine ratio in brain being higher $45 \mathrm{~min}$ after than that $7 \mathrm{~min}$ after administration. This observation is consistent with Zanos et al., 2016 (Zanos et al., 2016), showing that HNK administration may increase gamma power in mouse cortex. Overall, these findings suggest a temporal association between the prolonged increase in gamma power and the antidepressant-like effects of ketamine, 
inasmuch as the NMDA-R-antagonist-induced gamma oscillations could not be prevented by antipsychotic drugs (Jones et al., 2012). However, further investigations are needed to validate this variable as a potential biomarker.

In summary, the present study indicates that ketamine evokes a prominent fast and shortlasting decrease of the activity of thalamo-cortical circuits together with a decrease in delta oscillations, followed by a persistent increase of gamma oscillations. Further work is needed to address the functional implications of these observations and to fully understand the putative contributions of these effects to the psychotomimetic and antidepressant effects of ketamine. Finally, the direct comparison of the present ketamine study and past PCP studies (Kargieman et al., 2007; Santana et al., 2011; TroyanoRodriguez et al., 2014) allows us to conclude that non-competitive NDMA-R antagonists have markedly different, sometimes opposite, actions on neuronal activity, and cannot be taken as a homogenous group in regards to their in vivo actions on brain function. 


\section{Acknowledgements}

A partial account of the present study was presented at the $29^{\text {th }}$ Congress of the European College of Neuropsychopharmacology, Vienna 2016 and at the Society for Neuroscience 2017 Annual Meeting. We would like to thank Claus Agerskov for his skillful assistance in data processing, Lassina Badolo for his assistance with the quantitative bioanalysis and Mercedes Núñez Calvet for her technical assistance.

\section{Financial Disclosures}

The work leading to these results has received funding from Lundbeck $A / S$, the Innovation Fund Denmark and SAF2015-68346-P (Spanish Ministry of Economy and Competitiveness, co-financed by European Regional Development Fund (ERDF)) and PI12/00156 and PI16/00287 Instituto de Salud Carlos III, co-financed by European Regional Development Fund (ERDF)). Support from the Centro de Investigación Biomédica en Red de Salud Mental (CIBERSAM) and Generalitat de Catalunya Grup de Recerca Consolidat, 2014 SGR798 is also acknowledged.

\section{Conflict of interest}

FA has also received consultation fees from Lundbeck $A / S$ and is scientific advisor to Neurolixis. FA and $\mathrm{PC}$ are $\mathrm{PI}$ and co-PI of a research contract with Lundbeck $\mathrm{A} / \mathrm{S}$. MAF, KFH and NP are Lundbeck A/S employees. AAJ reported no potential conflicts of interest. 


\section{Figure Legends}

Figure 1. Recording sites and firing characteristics. (A) Schematic representation of thalamo-cortical projections. (B) Representative examples of firing characteristics of mediodorsal and centromedial thalamic (MD/CM) neurons, reticular thalamic (RtN) neurons and cortico-thalamic neurons in layer VI of the medial prefrontal cortex (mPFC). (C) Histological verification of representative neurons in the three different recording sites.

Figure 2. Effects of ketamine (Ket; 1, 2, $5 \mathrm{mg} / \mathrm{kg}$ i.v.) treatment on firing rate (A) and oscillatory activity ( $B$ and $C$ ) of RtN neurons. (A) Bar histogram representing the firing rate of the averaged last 2 min periods from a $5 \mathrm{~min}$ recording per treatment. The percentage represents the $2 \mathrm{~min}$ bins normalized to a stable 5 min baseline ( $n=13-12$ ) (* $p<0.05$ vs. Basal, $\# p<0.05$ vs. vehicle (Veh), $+p<0.05$ vs. Ket $2 \mathrm{mg} / \mathrm{kg}$ ). (B) Bar histogram representing the mean power (last 2 min periods from a 5 min recording per treatment) of each frequency band relative to the last $1 \mathrm{~min}$ baseline $(n=14)(* p<0.05$ vs. Veh, $\# p<0.05$ vs. Ket $1 \mathrm{mg} / \mathrm{kg}$ ). (C) Color-coded spectrogram plotted with $1 \mathrm{~Hz}$ resolution (y-axis). Each horizontal time bin represents the average spectral power per $1 \mathrm{~min}$ time bin normalized to the $5 \mathrm{~min}$ baseline period before vehicle administration $(n=14)$. Data are presented as average or percentage $(\%) \pm$ SEM.

Figure 3. Effects of ketamine (Ket; 1, 2, $5 \mathrm{mg} / \mathrm{kg}$ i.v.) treatment on firing rate ( $\mathrm{A}$ and $\mathrm{B}$ ) and oscillatory activity ( $C, D$ and $E$ ) of $M D / C M$ neurons. (A) Bar histogram representing the firing rate of the averaged last 2 min periods from a 5 min recording per treatment. The percentage represents the 2 min bins normalized to a stable 5 min baseline ( $n=12-11)$ ( $* p<0.05$ vs. Basal, $\# p<0.05$ vs. vehicle (Veh), $x p<0.05$ vs. Ket1, $+p<0.05$ vs. Ket2). (B) Bar histogram representing the effect of ketamine $5 \mathrm{mg} / \mathrm{kg}$ i.v. (cumulative dose) on the firing rate up to $15 \mathrm{~min}$ post-administration ( $n=6)\left({ }^{*} p<0.05\right.$ vs. Basal, \# $p<0.05$ vs. Veh, ^ $\mathrm{p}<0.05$ vs. Ket 5 at $15 \mathrm{~min}$. (C) Bar histogram representing the mean power (last 2 min periods from a 5 min recording per treatment) of each frequency band relative to the last 1 min baseline ( $n=13)$ (* $p<0.05$ vs. veh, \# $p<0.05$ vs. ket1). (D) Line histogram representing the mean power (last 2 min periods of 5 min bins) of each frequency band relative to the last $1 \mathrm{~min}$ baseline $(n=6)(* p<0.05 \mathrm{vs}$. $\min$ 10, \# $\mathrm{p}<0.05$ vs. min 25). (E) Color-coded spectrogram plotted with $1 \mathrm{~Hz}$ resolution (y-axis). Each horizontal time bin represents the average spectral power per $1 \mathrm{~min}$ time bin normalized to the $5 \mathrm{~min}$ baseline period before vehicle administration $(n=6)$. Data are presented as average or percentage $(\%) \pm$ SEM. 
Figure 4. Effects of ketamine (Ket; 1, 2, $5 \mathrm{mg} / \mathrm{kg}$ i.v.) treatment on firing rate of antidromically driven cortico-thalamic neurons (A) and oscillatory activity of layer VI infralimbic (IL) cortex (B, C and D). (A) Bar histogram representing the firing rate of the averaged last 2 min periods from a 5 min recording per treatment. The percentage represents the $2 \mathrm{~min}$ bins normalized to a stable 5 min baseline $(n=15-13)(*$ $p<0.05$ vs. Basal, \# $p<0.05$ vs. Veh $\not p<0.05$ vs. Ket $1 \mathrm{mg} / \mathrm{kg}$ ). (B) Bar histogram representing the mean power (last 2 min periods from a 5 min recording per treatment) of each frequency band relative to the last 1 min baseline ( $n=14)$ ( ${ }^{*} p<0.05$ vs. veh). (C) Line histogram representing the mean power (last 2 min periods from a 5 min recording per treatment) of each frequency band relative to the last 1 min baseline $(n=12)$ (* $p<0.05$ vs. $\min 10, \# p<0.05$ vs. min 25). (D) Color-coded spectrogram plotted with $1 \mathrm{~Hz}$ resolution (y-axis). Each horizontal time bin represents the average spectral power per 1 min time bin normalized to the 5 min baseline period before vehicle administration $(n=12)$. Data are presented as average or percentage $(\%) \pm$ SEM.

Figure 5. Schematic representation of thalamo-cortical connectivity (modified after Tronyano-Rodriguez et al., 2014) (Troyano-Rodriguez et al., 2014) with representative examples of the effect of ketamine on neuronal discharge in each of the areas examined. Ketamine induced a dramatic reduction of the discharge of GABAergic RtN neurons that tonically inhibit excitatory thalamic nuclei. Despite the reduced GABAergic inputs onto $\mathrm{MD} / \mathrm{CM}$ neurons resulting from ketamine's effect on RtN neurons, ketamine reduced the neuronal discharge in these thalamic nuclei, as well as in layer VI pyramidal neurons of the mPFC which project to thalamic excitatory (MD/CM among others) and inhibitory (RtN) nuclei. The activity of excitatory thalamic nuclei is also controlled by GABAergic structures of the basal ganglia circuit, such as ventral pallidum and substantia nigra reticulata (not examined in the present study). 


\section{References}

Anis, N. A., Berry, S.C., Burton, N.R., Lodge, D., 1983. The dissociative anaesthetics, ketamine and phencyclidine, selectively reduce excitation of central mammalian neurones by $\mathrm{N}$-methyl-aspartate. $\mathrm{Br}$. J. Pharmac 79, 565-575.

Arcelli, P., Frassoni, C., Regondi, M. C., De Biasi, S., Spreafico, R., 1997. GABAergic neurons in mammalian thalamus: a marker of thalamic complexity? Brain Res Bull 42, 27-37.

Autry, A. E., Adachi, M., Nosyreva, E., Na, E. S., Los, M. F., Cheng, P. F., Kavalali, E. T., Monteggia, L. M., 2011. NMDA receptor blockade at rest triggers rapid behavioural antidepressant responses. Nature 475, 91-95.

Beneyto, M., Kristiansen, L. V., Oni-Orisan, A., McCullumsmith, R. E., Meador-Woodruff, J. H., 2007. Abnormal glutamate receptor expression in the medial temporal lobe in schizophrenia and mood disorders. Neuropsychopharmacology 32, 1888-1902.

Browne, C. A., Lucki, I., 2013. Antidepressant effects of ketamine: mechanisms underlying fast-acting novel antidepressants. Front Pharmacol 4, 161.

Buzsaki, G., Draguhn, A., 2004. Neuronal oscillations in cortical networks. Science 304, 1926-1929.

Cardin, J. A., Carlen, M., Meletis, K., Knoblich, U., Zhang, F., Deisseroth, K., Tsai, L. H., Moore, C. I., 2009. Driving fast-spiking cells induces gamma rhythm and controls sensory responses. Nature 459, 663-667.

Carlen, M., Meletis, K., Siegle, J. H., Cardin, J. A., Futai, K., Vierling-Claassen, D., Ruhlmann, C., Jones, S. R., Deisseroth, K., Sheng, M., Moore, C. I., Tsai, L. H., 2012. A critical role for NMDA receptors in parvalbumin interneurons for gamma rhythm induction and behavior. Mol Psychiatry 17, 537-548.

Cunningham, M. O., Davies, C. H., Buhl, E. H., Kopell, N., Whittington, M. A., 2003. Gamma oscillations induced by kainate receptor activation in the entorhinal cortex in vitro. J Neurosci 23, 9761-9769.

Davies, S. N., Alford, S. T., Coan, E. J., Lester, R. A., Collingridge, G. L., 1988. Ketamine blocks an NMDA receptor-mediated component of synaptic transmission in rat hippocampus in a voltage-dependent manner. Neurosci Lett 92, 213-217.

Dawson, N., McDonald, M., Higham, D. J., Morris, B. J., Pratt, J. A., 2014. Subanesthetic ketamine treatment promotes abnormal interactions between neural subsystems and alters the properties of functional brain networks. Neuropsychopharmacology 39, 1786-1798.

Dawson, N., Morris, B. J., Pratt, J. A., 2013. Subanaesthetic ketamine treatment alters prefrontal cortex connectivity with thalamus and ascending subcortical systems. Schizophr Bull 39, 366-377.

De Simoni, S., Schwarz, A. J., O'Daly, O. G., Marquand, A. F., Brittain, C., Gonzales, C., Stephenson, S., Williams, S. C., Mehta, M. A., 2013. Test-retest reliability of the BOLD pharmacological MRI response to ketamine in healthy volunteers. Neuroimage 64, 75-90. 
Desta, Z., Moaddel, R., Ogburn, E. T., Xu, C., Ramamoorthy, A., Venkata, S. L., Sanghvi, M., Goldberg, M. E., Torjman, M. C., Wainer, I. W., 2012. Stereoselective and regiospecific hydroxylation of ketamine and norketamine. Xenobiotica 42, 1076-1087.

Downey, D., Dutta, A., McKie, S., Dawson, G. R., Dourish, C. T., Craig, K., Smith, M. A., McCarthy, D. J., Harmer, C. J., Goodwin, G. M., Williams, S., Deakin, J. F., 2016. Comparing the actions of lanicemine and ketamine in depression: key role of the anterior cingulate. Eur Neuropsychopharmacol 26, 994-1003.

Doyle, O. M., De Simoni, S., Schwarz, A. J., Brittain, C., O'Daly, O. G., Williams, S. C., Mehta, M. A., 2013. Quantifying the attenuation of the ketamine pharmacological magnetic resonance imaging response in humans: a validation using antipsychotic and glutamatergic agents. J Pharmacol Exp Ther 345, 151-160.

Dravid, S. M., Erreger, K., Yuan, H., Nicholson, K., Le, P., Lyuboslavsky, P., Almonte, A., Murray, E., Mosely, C., Barber, J., French, A., Balster, R., Murray, T. F., Traynelis, S. F., 2007. Subunit-specific mechanisms and proton sensitivity of NMDA receptor channel block. J Physiol 581, 107-128.

Duman, R. S., Aghajanian, G. K., 2012. Synaptic dysfunction in depression: potential therapeutic targets. Science 338, 68-72.

Ferrari, A. J., Charlson, F. J., Norman, R. E., Patten, S. B., Freedman, G., Murray, C. J., Vos, T., Whiteford, H. A., 2013. Burden of depressive disorders by country, sex, age, and year: findings from the global burden of disease study 2010. PLoS Med 10, e1001547.

Feyissa, A. M., Chandran, A., Stockmeier, C. A., Karolewicz, B., 2009. Reduced levels of NR2A and NR2B subunits of NMDA receptor and PSD-95 in the prefrontal cortex in major depression. Prog Neuropsychopharmacol Biol Psychiatry 33, 70-75.

Fuchikami, M., Thomas, A., Liu, R., Wohleb, E. S., Land, B. B., DiLeone, R. J., Aghajanian, G. K., Duman, R. S., 2015. Optogenetic stimulation of infralimbic PFC reproduces ketamine's rapid and sustained antidepressant actions. Proc Natl Acad Sci U S A 112, 8106-8111.

Fukumoto, K., lijima, M., Chaki, S., 2016. The Antidepressant Effects of an mGlu2/3 Receptor Antagonist and Ketamine Require AMPA Receptor Stimulation in the mPFC and Subsequent Activation of the 5-HT Neurons in the DRN. Neuropsychopharmacology 41, 1046-1056.

Gabbott, P. L., Warner, T. A., Jays, P. R., Salway, P., Busby, S. J., 2005. Prefrontal cortex in the rat: projections to subcortical autonomic, motor, and limbic centers. J Comp Neurol 492, 145-177.

Gasull-Camos, J., Tarres-Gatius, M., Artigas, F., Castane, A., 2017. Glial GLT-1 blockade in infralimbic cortex as a new strategy to evoke rapid antidepressant-like effects in rats. Transl Psychiatry 7, e1038.

Gilling, K. E., Jatzke, C., Hechenberger, M., Parsons, C. G., 2009. Potency, voltage-dependency, agonist concentration-dependency, blocking kinetics and partial untrapping of the uncompetitive N-methyl-Daspartate (NMDA) channel blocker memantine at human NMDA (GluN1/GluN2A) receptors. Neuropharmacology 56, 866-875.

Groenewegen, H. J., Uylings, H. B. M., 2000. The prefrontal cortex and the integration of sensory, limbic and autonomic information. Progress in Brain Research 126, 3-28. 
Hakami, T., Jones, N. C., Tolmacheva, E. A., Gaudias, J., Chaumont, J., Salzberg, M., O'Brien, T. J., Pinault, D., 2009. NMDA receptor hypofunction leads to generalized and persistent aberrant gamma oscillations independent of hyperlocomotion and the state of consciousness. PLoS One 4, e6755.

Hanson, J. E., Weber, M., Meilandt, W. J., Wu, T., Luu, T., Deng, L., Shamloo, M., Sheng, M., ScearceLevie, K., Zhou, Q., 2013. GluN2B antagonism affects interneurons and leads to immediate and persistent changes in synaptic plasticity, oscillations, and behavior. Neuropsychopharmacology 38 , 1221-1233.

Hasler, G., van der Veen, J. W., Tumonis, T., Meyers, N., Shen, J., Drevets, W. C., 2007. Reduced prefrontal glutamate/glutamine and gamma-aminobutyric acid levels in major depression determined using proton magnetic resonance spectroscopy. Arch Gen Psychiatry 64, 193-200.

Hillhouse, T. M., Porter, J. H., Negus, S. S., 2014. Comparison of antidepressant-like and abuse-related effects of phencyclidine in rats. Drug Dev Res 75, 479-488.

Hiyoshi, T., Hikichi, H., Karasawa, J., Chaki, S., 2014. Metabotropic glutamate receptors regulate cortical gamma hyperactivities elicited by ketamine in rats. Neurosci Lett 567, 30-34.

Homayoun, H., Moghaddam, B., 2007. NMDA receptor hypofunction produces opposite effects on prefrontal cortex interneurons and pyramidal neurons. J Neurosci 27, 11496-11500.

Jackson, M. E., Homayoun, H., Moghaddam, B., 2004. NMDA receptor hypofunction produces concomitant firing rate potentiation and burst activity reduction in the prefrontal cortex. Proc Natl Acad Sci U S A 101, 8467-8472.

Jodo, E., Suzuki, Y., Takeuchi, S., Niwa, S., Kayama, Y., 2003. Different effects of phencyclidine and methamphetamine on firing activity of medial prefrontal cortex neurons in freely moving rats. Brain Res 962, 226-231.

Jones, N. C., Reddy, M., Anderson, P., Salzberg, M. R., O'Brien, T. J., Pinault, D., 2012. Acute administration of typical and atypical antipsychotics reduces EEG gamma power, but only the preclinical compound LY379268 reduces the ketamine-induced rise in gamma power. Int J Neuropsychopharmacol $15,657-668$.

Karavanova, I., Vasudevan, K., Cheng, J., Buonanno, A., 2007. Novel regional and developmental NMDA receptor expression patterns uncovered in NR2C subunit-beta-galactosidase knock-in mice. Mol Cell Neurosci 34, 468-480.

Kargieman, L., Santana, N., Mengod, G., Celada, P., Artigas, F., 2007. Antipsychotic drugs reverse the disruption in prefrontal cortex function produced by NMDA receptor blockade with phencyclidine. Proc Natl Acad Sci U S A 104, 14843-14848.

Kassebaum, N. J., Arora, M., Barber, R. M., Bhutta, Z. A., Brown, J., Carter, A., Casey, D. C., Charlson, F. J., Coates, M. M., Coggeshall, M., Cornaby, L., Dandona, L., Dicker, D. J., Erskine, H. E., Ferrari, A. J., Fitzmaurice, C., Foreman, K., Forouzanfar, M. H., Fullman, N., Gething, P. W., Goldberg, E. M., Graetz, N., Haagsma, J. A., Hay, S. I., Johnson, C. O., Kemmer, L., Khalil, I. A., Kinfu, Y., Kutz, M. J., Kyu, H. H., Leung, J., Liang, X., Lim, S. S., Lozano, R., Mensah, G. A., Mikesell, J., Mokdad, A. H., Mooney, M. D., Naghavi, M., Nguyen, G., Nsoesie, E., Pigott, D. M., Pinho, C., Rankin, Z., Reinig, N., Salomon, J. A., Sandar, L., Smith, 
A., Sorensen, R. J. D., Stanaway, J., Steiner, C., Teeple, S., Troeger, C., Truelsen, T., VanderZanden, A., Wagner, J. A., Wanga, V., Whiteford, H. A., Zhou, M., Zoeckler, L., Abajobir, A. A., Abate, K. H., Abbafati, C., Abbas, K. M., Abd-Allah, F., Abraham, B., Abubakar, I., Abu-Raddad, L. J., Abu-Rmeileh, N. M. E., Achoki, T., Ackerman, I. N., Adebiyi, A. O., Adedeji, I. A., Adsuar, J. C., Afanvi, K. A., Afshin, A., Agardh, E. E., Agarwal, A., Agarwal, S. K., Ahmed, M. B., Kiadaliri, A. A., Ahmadieh, H., Akseer, N., Al-Aly, Z., Alam, K., Alam, N. K. M., Aldhahri, S. F., Alegretti, M. A., Aleman, A. V., Alemu, Z. A., Alexander, L. T., Ali, R., Alkerwi, A. a., Alla, F., Allebeck, P., Allen, C., Alsharif, U., Altirkawi, K. A., Martin, E. A., Alvis-Guzman, N., Amare, A. T., Amberbir, A., Amegah, A. K., Amini, H., Ammar, W., Amrock, S. M., Anderson, G. M., Anderson, B. O., Antonio, C. A. T., Anwari, P., Ärnlöv, J., Arsenijevic, V. S. A., Artaman, A., Asayesh, H., Asghar, R. J., Avokpaho, E. F. G. A., Awasthi, A., Quintanilla, B. P. A., Azzopardi, P., Bacha, U., Badawi, A., Balakrishnan, K., Banerjee, A., Barac, A., Barker-Collo, S. L., Bärnighausen, T., Barregard, L., Barrero, L. H., Basu, S., Bayou, T. A., Beardsley, J., Bedi, N., Beghi, E., Bell, B., Bell, M. L., Benjet, C., Bennett, D. A., Bensenor, I. M., Berhane, A., Bernabé, E., Betsu, B. D., Beyene, A. S., Bhala, N., Bhansali, A., Bhatt, S., Biadgilign, S., Bienhoff, K., Bikbov, B., Abdulhak, A. A. B., Biryukov, S., Bisanzio, D., Bjertness, E., Blore, J. D., Borschmann, R., Boufous, S., Bourne, R. R. A., Brainin, M., Brazinova, A., Breitborde, N. J. K., Brugha, T. S., Buchbinder, R., Buckle, G. C., Butt, Z. A., Calabria, B., Campos-Nonato, I. R., Campuzano, J. C., Carabin, H., Carapetis, J. R., Cárdenas, R., Carrero, J. J., Castañeda-Orjuela, C. A., Rivas, J. C., CataláLópez, F., Cavalleri, F., Chang, J.-C., Chiang, P. P.-C., Chibalabala, M., Chibueze, C. E., Chisumpa, V. H., Choi, J.-Y. J., Choudhury, L., Christensen, H., Ciobanu, L. G., Colistro, V., Colomar, M., Colquhoun, S. M., Cortinovis, M., Crump, J. A., Damasceno, A., Dandona, R., Dargan, P. I., das Neves, J., Davey, G., Davis, A. C., Leo, D. D., Degenhardt, L., Gobbo, L. C. D., Derrett, S., Jarlais, D. C. D., deVeber, G. A., Dharmaratne, S. D., Dhillon, P. K., Ding, E. L., Doyle, K. E., Driscoll, T. R., Duan, L., Dubey, M., Duncan, B. B., Ebrahimi, H., Ellenbogen, R. G., Elyazar, I., Endries, A. Y., Ermakov, S. P., Eshrati, B., Esteghamati, A., Estep, K., Fahimi, S., Farid, T. A., Farinha, C. S. e. S., Faro, A., Farvid, M. S., Farzadfar, F., Feigin, V. L., Fereshtehnejad, S.-M., Fernandes, J. G., Fernandes, J. C., Fischer, F., Fitchett, J. R. A., Foigt, N., Fowkes, F. G. R., Franklin, R. C., Friedman, J., Frostad, J., Fürst, T., Futran, N. D., Gabbe, B., Gankpé, F. G., Garcia-Basteiro, A. L., Gebrehiwot, T. T., Gebremedhin, A. T., Geleijnse, J. M., Gibney, K. B., Gillum, R. F., Ginawi, I. A. M., Giref, A. Z., Giroud, M., Gishu, M. D., Giussani, G., Godwin, W. W., Gomez-Dantes, H., Gona, P., Goodridge, A., Gopalani, S. V., Gotay, C. C., Goto, A., Gouda, H. N., Gugnani, H., Guo, Y., Gupta, R., Gupta, R., Gupta, V., Gutiérrez, R. A., Hafezi-Nejad, N., Haile, D., Hailu, A. D., Hailu, G. B., Halasa, Y. A., Hamadeh, R. R., Hamidi, S., Hammami, M., Handal, A. J., Hankey, G. J., Harb, H. L., Harikrishnan, S., Haro, J. M., Hassanvand, M. S., Hassen, T. A., Havmoeller, R., Hay, R. J., Hedayati, M. T., Heredia-Pi, I. B., Heydarpour, P., Hoek, H. W., Hoffman, D. J., Horino, M., Horita, N., Hosgood, H. D., Hoy, D. G., Hsairi, M., Huang, H., Huang, J. J., Iburg, K. M., Idrisov, B. T., Innos, K., Inoue, M., Jacobsen, K. H., Jauregui, A., Jayatilleke, A. U., Jeemon, P., Jha, V., Jiang, G., Jiang, Y., Jibat, T., Jimenez-Corona, A., Jin, Y., Jonas, J. B., Kabir, Z., Kajungu, D. K., Kalkonde, Y., Kamal, R., Kan, H., Kandel, A., Karch, A., Karema, C. K., Karimkhani, C., Kasaeian, A., Katibeh, M., Kaul, A., Kawakami, N., Kazi, D. S., Keiyoro, P. N., Kemp, A. H., Kengne, A. P., Keren, A., Kesavachandran, C. N., Khader, Y. S., Khan, A. R., Khan, E. A., Khang, Y.-H., Khoja, T. A. M., Khubchandani, J., Kieling, C., Kim, C.-i., Kim, D., Kim, Y. J., Kissoon, N., Kivipelto, M., Knibbs, L. D., Knudsen, A. K., Kokubo, Y., Kolte, D., Kopec, J. A., Koul, P. A., Koyanagi, A., Defo, B. K., Kuchenbecker, R. S., Bicer, B. K., Kuipers, E. J., Kumar, G. A., Kwan, G. F., Lalloo, R., Lallukka, T., Larsson, A., Latif, A. A., Lavados, P. M., Lawrynowicz, A. E. B., Leasher, J. L., Leigh, J., Leung, R., Li, Y., Li, Y., Lipshultz, S. E., Liu, P. Y., Liu, Y., Lloyd, B. K., Logroscino, G., Looker, K. J., Lotufo, P. A., Lucas, R. M., Lunevicius, R., Lyons, R. A., Razek, H. M. A. E., Mahdavi, M., Majdan, M., Majeed, A., Malekzadeh, R., Malta, D. C., Marcenes, W., Martinez-Raga, J., Masiye, F., Mason-Jones, A. J., Matzopoulos, R., Mayosi, B. M., McGrath, J. J., McKee, M., Meaney, P. A., Mehari, A., Melaku, Y. A., Memiah, P., Memish, Z. A., Mendoza, W., Meretoja, A., Meretoja, T. J., Mesfin, Y. M., Mhimbira, F. A., Millear, A., Miller, T. R., Mills, E. J., Mirarefin, M., Mirrakhimov, E. M., Mitchell, P. B., Mock, C. N., Mohammad, K. A., Mohammadi, A., Mohammed, S., Monasta, L., Hernandez, J. C. M., 
Montico, M., Moradi-Lakeh, M., Mori, R., Mueller, U. O., Mumford, J. E., Murdoch, M. E., Murthy, G. V. S., Nachega, J. B., Naheed, A., Naldi, L., Nangia, V., Newton, J. N., Ng, M., Ngalesoni, F. N., Nguyen, Q. L., Nisar, M. I., Pete, P. M. N., Nolla, J. M., Norheim, O. F., Norman, R. E., Norrving, B., Obermeyer, C. M., Ogbo, F. A., Oh, I.-H., Oladimeji, O., Olivares, P. R., Olusanya, B. O., Olusanya, J. O., Oren, E., Ortiz, A., Ota, E., Oyekale, A. S., Pa, M., Park, E.-K., Parsaeian, M., Patten, S. B., Patton, G. C., Pedro, J. M., Pereira, D. M., Perico, N., Pesudovs, K., Petzold, M., Phillips, M. R., Piel, F. B., Pillay, J. D., Pishgar, F., Plass, D., Polinder, S., Popova, S., Poulton, R. G., Pourmalek, F., Prasad, N. M., Qorbani, M., Rabiee, R. H. S., Radfar, A., Rafay, A., Rahimi, K., Rahimi-Movaghar, V., Rahman, M., Rahman, M. H. U., Rahman, S. U., Rai, D., Rai, R. K., Rajsic, S., Raju, M., Ram, U., Ranganathan, K., Refaat, A. H., Reitsma, M. B., Remuzzi, G., Resnikoff, S., Reynolds, A., Ribeiro, A. L., Ricci, S., Roba, H. S., Rojas-Rueda, D., Ronfani, L., Roshandel, G., Roth, G. A., Roy, A., Sackey, B. B., Sagar, R., Sanabria, J. R., Sanchez-Niño, M. D., Santos, I. S., Santos, J. V., Sarmiento-Suarez, R., Sartorius, B., Satpathy, M., Savic, M., Sawhney, M., Schmidt, M. I., Schneider, I. J. C., Schutte, A. E., Schwebel, D. C., Seedat, S., Sepanlou, S. G., Servan-Mori, E. E., Shahraz, S., Shaikh, M. A., Sharma, R., She, J., Sheikhbahaei, S., Shen, J., Sheth, K. N., Shibuya, K., Shigematsu, M., Shin, M.-J., Shiri, R., Sigfusdottir, I. D., Silva, D. A. S., Silverberg, J. I., Simard, E. P., Singh, A., Singh, J. A., Singh, P. K., Skirbekk, V., Skogen, J. C., Soljak, M., Søreide, K., Sorensen, R. J. D., Sreeramareddy, C. T., Stathopoulou, V., Steel, N., Stein, D. J., Stein, M. B., Steiner, T. J., Stovner, L. J., Stranges, S., Stroumpoulis, K., Sunguya, B. F., Sur, P. J., Swaminathan, S., Sykes, B. L., Szoeke, C. E. I., Tabarés-Seisdedos, R., Tandon, N., Tanne, D., Tavakkoli, M., Taye, B., Taylor, H. R., Ao, B. J. T., Tegegne, T. K., Tekle, D. Y., Terkawi, A. S., Tessema, G. A., Thakur, J. S., Thomson, A. J., Thorne-Lyman, A. L., Thrift, A. G., Thurston, G. D., Tobe-Gai, R., Tonelli, M., Topor-Madry, R., Topouzis, F., Tran, B. X., Truelsen, T., Dimbuene, Z. T., Tsilimbaris, M., Tura, A. K., Tuzcu, E. M., Tyrovolas, S., Ukwaja, K. N., Undurraga, E. A., Uneke, C. J., Uthman, O. A., van Gool, C. H., van Os, J., Vasankari, T., Vasconcelos, A. M. N., Venketasubramanian, N., Violante, F. S., Vlassov, V. V., Vollset, S. E., Wagner, G. R., Wallin, M. T., Wang, L., Weichenthal, S., Weiderpass, E., Weintraub, R. G., Werdecker, A., Westerman, R., Wijeratne, T., Wilkinson, J. D., Williams, H. C., Wiysonge, C. S., Woldeyohannes, S. M., Wolfe, C. D. A., Won, S., Xu, G., Yadav, A. K., Yakob, B., Yan, L. L., Yano, Y., Yaseri, M., Ye, P., Yip, P., Yonemoto, N., Yoon, S.-J., Younis, M. Z., Yu, C., Zaidi, Z., Zaki, M. E. S., Zeeb, H., Zodpey, S., Zonies, D., Zuhlke, L. J., Vos, T., Lopez, A. D., Murray, C. J. L., Global, regional, and national disability-adjusted life-years (DALYs) for 315 diseases and injuries and healthy life expectancy (HALE), 1990\&\#x2013;2015: a systematic analysis for the Global Burden of Disease Study 2015. The Lancet 388, $1603-1658$.

Kessler, R. C., Berglund, P., Demler, O., Jin, R., Koretz, D., Merikangas, K. R., Rush, A. J., Walters, E. E., Wang, P. S., 2003. The epidemiology of major depressive disorder: results from the National Comorbidity Survey Replication (NCS-R). Jama 289, 3095-3105.

Khlestova, E., Johnson, J. W., Krystal, J. H., Lisman, J., 2016. The Role of GluN2C-Containing NMDA Receptors in Ketamine's Psychotogenic Action and in Schizophrenia Models. J Neurosci 36, 1115111157.

Kiss, T., Hoffmann, W. E., Scott, L., Kawabe, T. T., Milici, A. J., Nilsen, E. A., Hajos, M., 2011. Role of Thalamic Projection in NMDA Receptor-Induced Disruption of Cortical Slow Oscillation and Short-Term Plasticity. Front Psychiatry 2, 14.

Kittelberger, K., Hur, E. E., Sazegar, S., Keshavan, V., Kocsis, B., 2012. Comparison of the effects of acute and chronic administration of ketamine on hippocampal oscillations: relevance for the NMDA receptor hypofunction model of schizophrenia. Brain Struct Funct 217, 395-409. 
Koike, H., Chaki, S., 2014. Requirement of AMPA receptor stimulation for the sustained antidepressant activity of ketamine and LY341495 during the forced swim test in rats. Behav Brain Res 271, 111-115.

Kotermanski, S. E., Johnson, J. W., 2009. Mg2+ imparts NMDA receptor subtype selectivity to the Alzheimer's drug memantine. J Neurosci 29, 2774-2779.

Kuroda, M., Yokofujita, J., Murakami, K., 1998. An ultrastructural study of the neural circuit between the prefrontal cortex and the mediodorsal nucleus of the thalamus. Prog Neurobiol 54, 417-458.

Laviolette, S. R., Lipski, W. J., Grace, A. A., 2005. A subpopulation of neurons in the medial prefrontal cortex encodes emotional learning with burst and frequency codes through a dopamine D4 receptordependent basolateral amygdala input. J Neurosci 25, 6066-6075.

Li, C. T., Chen, M. H., Lin, W. C., Hong, C. J., Yang, B. H., Liu, R. S., Tu, P. C., Su, T. P., 2016. The effects of low-dose ketamine on the prefrontal cortex and amygdala in treatment-resistant depression: $\mathrm{A}$ randomized controlled study. Hum Brain Mapp 37, 1080-1090.

Li, N., Lee, B., Liu, R. J., Banasr, M., Dwyer, J. M., Iwata, M., Li, X. Y., Aghajanian, G., Duman, R. S., 2010. mTOR-dependent synapse formation underlies the rapid antidepressant effects of NMDA antagonists. Science 329, 959-964.

Li, N., Liu, R. J., Dwyer, J. M., Banasr, M., Lee, B., Son, H., Li, X. Y., Aghajanian, G., Duman, R. S., 2011. Glutamate N-methyl-D-aspartate receptor antagonists rapidly reverse behavioral and synaptic deficits caused by chronic stress exposure. Biol Psychiatry 69, 754-761.

Littlewood, C. L., Cash, D., Dixon, A. L., Dix, S. L., White, C. T., O'Neill, M. J., Tricklebank, M., Williams, S. C., 2006. Using the BOLD MR signal to differentiate the stereoisomers of ketamine in the rat. Neuroimage 32, 1733-1746.

Llado-Pelfort, L., Troyano-Rodriguez, E., van den Munkhof, H. E., Cervera-Ferri, A., Jurado, N., NunezCalvet, M., Artigas, F., Celada, P., 2016. Phencyclidine-induced disruption of oscillatory activity in prefrontal cortex: Effects of antipsychotic drugs and receptor ligands. Eur Neuropsychopharmacol 26, 614-625.

MacDonald, J. F., Bartlett, M. C., Mody, I., Pahapill, P., Reynolds, J. N., Salter, M. W., Schneiderman, J. H., Pennefather, P. S., 1991. Actions of ketamine, phencyclidine and MK-801 on NMDA receptor currents in cultured mouse hippocampal neurones. J Physiol 432, 483-508.

Maeng, S., Zarate, C. A., Jr., Du, J., Schloesser, R. J., McCammon, J., Chen, G., Manji, H. K., 2008. Cellular mechanisms underlying the antidepressant effects of ketamine: role of alpha-amino-3-hydroxy-5methylisoxazole-4-propionic acid receptors. Biol Psychiatry 63, 349-352.

Maltbie, E., Gopinath, K., Urushino, N., Kempf, D., Howell, L., 2016. Ketamine-induced brain activation in awake female nonhuman primates: a translational functional imaging model. Psychopharmacology (Berl) 233, 961-972.

Miller, O. H., Bruns, A., Ben Ammar, I., Mueggler, T., Hall, B. J., 2017. Synaptic Regulation of a Thalamocortical Circuit Controls Depression-Related Behavior. Cell Rep 20, 1867-1880. 
Mion, G., Villevieille, T., 2013. Ketamine pharmacology: an update (pharmacodynamics and molecular aspects, recent findings). CNS Neurosci Ther 19, 370-380.

Moghaddam, B., Adams, B., Verma, A., Daly, D., 1997. Activation of glutamatergic neurotransmission by ketamine: a novel step in the pathway from NMDA receptor blockade to dopaminergic and cognitive disruptions associated with the prefrontal cortex. J Neurosci 17, 2921-2927.

Monteggia, L. M., Zarate, C., Jr., 2015. Antidepressant actions of ketamine: from molecular mechanisms to clinical practice. Curr Opin Neurobiol 30, 139-143.

Monyer, H., Burnashev, N., Laurie, D. J., Sakmann, B., Seeburg, P. H., 1994. Developmental and regional expression in the rat brain and functional properties of four NMDA receptors. Neuron 12, 529-540.

Murray, C. J., Vos, T., Lozano, R., Naghavi, M., Flaxman, A. D., Michaud, C., Ezzati, M., Shibuya, K., Salomon, J. A., Abdalla, S., Aboyans, V., Abraham, J., Ackerman, I., Aggarwal, R., Ahn, S. Y., Ali, M. K., Alvarado, M., Anderson, H. R., Anderson, L. M., Andrews, K. G., Atkinson, C., Baddour, L. M., Bahalim, A. N., Barker-Collo, S., Barrero, L. H., Bartels, D. H., Basanez, M. G., Baxter, A., Bell, M. L., Benjamin, E. J., Bennett, D., Bernabe, E., Bhalla, K., Bhandari, B., Bikbov, B., Bin Abdulhak, A., Birbeck, G., Black, J. A., Blencowe, H., Blore, J. D., Blyth, F., Bolliger, I., Bonaventure, A., Boufous, S., Bourne, R., Boussinesq, M., Braithwaite, T., Brayne, C., Bridgett, L., Brooker, S., Brooks, P., Brugha, T. S., Bryan-Hancock, C., Bucello, C., Buchbinder, R., Buckle, G., Budke, C. M., Burch, M., Burney, P., Burstein, R., Calabria, B., Campbell, B., Canter, C. E., Carabin, H., Carapetis, J., Carmona, L., Cella, C., Charlson, F., Chen, H., Cheng, A. T., Chou, D., Chugh, S. S., Coffeng, L. E., Colan, S. D., Colquhoun, S., Colson, K. E., Condon, J., Connor, M. D., Cooper, L. T., Corriere, M., Cortinovis, M., de Vaccaro, K. C., Couser, W., Cowie, B. C., Criqui, M. H., Cross, M., Dabhadkar, K. C., Dahiya, M., Dahodwala, N., Damsere-Derry, J., Danaei, G., Davis, A., De Leo, D., Degenhardt, L., Dellavalle, R., Delossantos, A., Denenberg, J., Derrett, S., Des Jarlais, D. C., Dharmaratne, S. D., Dherani, M., Diaz-Torne, C., Dolk, H., Dorsey, E. R., Driscoll, T., Duber, H., Ebel, B., Edmond, K., Elbaz, A., Ali, S. E., Erskine, H., Erwin, P. J., Espindola, P., Ewoigbokhan, S. E., Farzadfar, F., Feigin, V., Felson, D. T., Ferrari, A., Ferri, C. P., Fevre, E. M., Finucane, M. M., Flaxman, S., Flood, L., Foreman, K., Forouzanfar, M. H., Fowkes, F. G., Fransen, M., Freeman, M. K., Gabbe, B. J., Gabriel, S. E., Gakidou, E., Ganatra, H. A., Garcia, B., Gaspari, F., Gillum, R. F., Gmel, G., Gonzalez-Medina, D., Gosselin, R., Grainger, R., Grant, B., Groeger, J., Guillemin, F., Gunnell, D., Gupta, R., Haagsma, J., Hagan, H., Halasa, Y. A., Hall, W., Haring, D., Haro, J. M., Harrison, J. E., Havmoeller, R., Hay, R. J., Higashi, H., Hill, C., Hoen, B., Hoffman, H., Hotez, P. J., Hoy, D., Huang, J. J., Ibeanusi, S. E., Jacobsen, K. H., James, S. L., Jarvis, D., Jasrasaria, R., Jayaraman, S., Johns, N., Jonas, J. B., Karthikeyan, G., Kassebaum, N., Kawakami, N., Keren, A., Khoo, J. P., King, C. H., Knowlton, L. M., Kobusingye, O., Koranteng, A., Krishnamurthi, R., Laden, F., Lalloo, R., Laslett, L. L., Lathlean, T., Leasher, J. L., Lee, Y. Y., Leigh, J., Levinson, D., Lim, S. S., Limb, E., Lin, J. K., Lipnick, M., Lipshultz, S. E., Liu, W., Loane, M., Ohno, S. L., Lyons, R., Mabweijano, J., MacIntyre, M. F., Malekzadeh, R., Mallinger, L., Manivannan, S., Marcenes, W., March, L., Margolis, D. J., Marks, G. B., Marks, R., Matsumori, A., Matzopoulos, R., Mayosi, B. M., McAnulty, J. H., McDermott, M. M., McGill, N., McGrath, J., Medina-Mora, M. E., Meltzer, M., Mensah, G. A., Merriman, T. R., Meyer, A. C., Miglioli, V., Miller, M., Miller, T. R., Mitchell, P. B., Mock, C., Mocumbi, A. O., Moffitt, T. E., Mokdad, A. A., Monasta, L., Montico, M., Moradi-Lakeh, M., Moran, A., Morawska, L., Mori, R., Murdoch, M. E., Mwaniki, M. K., Naidoo, K., Nair, M. N., Naldi, L., Narayan, K. M., Nelson, P. K., Nelson, R. G., Nevitt, M. C., Newton, C. R., Nolte, S., Norman, P., Norman, R., O'Donnell, M., O'Hanlon, S., Olives, C., Omer, S. B., Ortblad, K., Osborne, R., Ozgediz, D., Page, A., Pahari, B., Pandian, J. D., Rivero, A. P., Patten, S. B., Pearce, N., Padilla, R. P., Perez-Ruiz, F., Perico, N., Pesudovs, K., Phillips, D., Phillips, M. R., Pierce, K., Pion, S., Polanczyk, G. V., Polinder, S., Pope, C. A., 3rd, Popova, S., Porrini, E., Pourmalek, F., Prince, M., Pullan, R. L., Ramaiah, 
K. D., Ranganathan, D., Razavi, H., Regan, M., Rehm, J. T., Rein, D. B., Remuzzi, G., Richardson, K., Rivara, F. P., Roberts, T., Robinson, C., De Leon, F. R., Ronfani, L., Room, R., Rosenfeld, L. C., Rushton, L., Sacco, R. L., Saha, S., Sampson, U., Sanchez-Riera, L., Sanman, E., Schwebel, D. C., Scott, J. G., Segui-Gomez, M., Shahraz, S., Shepard, D. S., Shin, H., Shivakoti, R., Singh, D., Singh, G. M., Singh, J. A., Singleton, J., Sleet, D. A., Sliwa, K., Smith, E., Smith, J. L., Stapelberg, N. J., Steer, A., Steiner, T., Stolk, W. A., Stovner, L. J., Sudfeld, C., Syed, S., Tamburlini, G., Tavakkoli, M., Taylor, H. R., Taylor, J. A., Taylor, W. J., Thomas, B., Thomson, W. M., Thurston, G. D., Tleyjeh, I. M., Tonelli, M., Towbin, J. A., Truelsen, T., Tsilimbaris, M. K., Ubeda, C., Undurraga, E. A., van der Werf, M. J., van Os, J., Vavilala, M. S., Venketasubramanian, N., Wang, M., Wang, W., Watt, K., Weatherall, D. J., Weinstock, M. A., Weintraub, R., Weisskopf, M. G., Weissman, M. M., White, R. A., Whiteford, H., Wiebe, N., Wiersma, S. T., Wilkinson, J. D., Williams, H. C., Williams, S. R., Witt, E., Wolfe, F., Woolf, A. D., Wulf, S., Yeh, P. H., Zaidi, A. K., Zheng, Z. J., Zonies, D., Lopez, A. D., AlMazroa, M. A., Memish, Z. A., 2012. Disability-adjusted life years (DALYs) for 291 diseases and injuries in 21 regions, 1990-2010: a systematic analysis for the Global Burden of Disease Study 2010. Lancet 380, 2197-2223.

Neal, H., Bond, A., 1985. Quantitative electrocortical changes in the rat induced by phencyclidine and other stimulants. Neuropharmacology 24, 317-323.

Newport, D. J., Carpenter, L. L., McDonald, W. M., Potash, J. B., Tohen, M., Nemeroff, C. B., Biomarkers, A. P. A. C. o. R. T. F. o. N., Treatments, 2015. Ketamine and Other NMDA Antagonists: Early Clinical Trials and Possible Mechanisms in Depression. Am J Psychiatry 172, 950-966.

Ohara, P. T., Lieberman, A. R., Hunt, S. P., Wu, J. Y., 1983. Neural elements containing glutamic acid decarboxylase $(G A D)$ in the dorsal lateral geniculate nucleus of the rat; immunohistochemical studies by light and electron microscopy. Neuroscience 8, 189-211.

Paxinos, G., Watson, C., 2007. The Rat Brain in Stereotaxic Coordinates. Academic Press.

Penn, E., Tracy, D. K., 2012. The drugs don't work? antidepressants and the current and future pharmacological management of depression. Ther Adv Psychopharmacol 2, 179-188.

Phillips, K. G., Cotel, M. C., McCarthy, A. P., Edgar, D. M., Tricklebank, M., O'Neill, M. J., Jones, M. W., Wafford, K. A., 2012. Differential effects of NMDA antagonists on high frequency and gamma EEG oscillations in a neurodevelopmental model of schizophrenia. Neuropharmacology 62, 1359-1370.

Pinault, D., 2004. The thalamic reticular nucleus: structure, function and concept. Brain Res Brain Res Rev 46, 1-31.

Pinault, D., 2008. N-methyl d-aspartate receptor antagonists ketamine and MK-801 induce wake-related aberrant gamma oscillations in the rat neocortex. Biol Psychiatry 63, 730-735.

Pirot, S., Glowinski, J., Thierry, A. M., 1995. Excitatory responses evoked in prefrontal cortex by mediodorsal thalamic nucleus stimulation: influence of anaesthesia. Eur J Pharmacol 285, 45-54.

Pirot, S., Jay, T. M., Glowinski, J., Thierry, A. M., 1994. Anatomical and electrophysiological evidence for an excitatory amino acid pathway from the thalamic mediodorsal nucleus to the prefrontal cortex in the rat. Eur J Neurosci 6, 1225-1234. 
Popp, S., Behl, B., Joshi, J. J., Lanz, T. A., Spedding, M., Schenker, E., Jay, T. M., Svenningsson, P., Caudal, D., Cunningham, J. I., Deaver, D., Bespalov, A., 2016. In search of the mechanisms of ketamine's antidepressant effects: How robust is the evidence behind the mTor activation hypothesis. F1000Research 5, 634.

Quirk, M. C., Sosulski, D. L., Feierstein, C. E., Uchida, N., Mainen, Z. F., 2009. A defined network of fastspiking interneurons in orbitofrontal cortex: responses to behavioral contingencies and ketamine administration. Front Syst Neurosci 3, 13.

Rush, A. J., Trivedi, M. H., Wisniewski, S. R., Nierenberg, A. A., Stewart, J. W., Warden, D., Niederehe, G., Thase, M. E., Lavori, P. W., Lebowitz, B. D., McGrath, P. J., Rosenbaum, J. F., Sackeim, H. A., Kupfer, D. J., Luther, J., Fava, M., 2006. Acute and longer-term outcomes in depressed outpatients requiring one or several treatment steps: a STAR*D report. Am J Psychiatry 163, 1905-1917.

Sanacora, G., 2009. Do glutamatergic agents represent a new class of antidepressant drugs? Part 2. J Clin Psychiatry 70, 1604-1605.

Sanacora, G., Heimer, H., Hartman, D., Mathew, S. J., Frye, M., Nemeroff, C., Robinson Beale, R., 2017. Balancing the Promise and Risks of Ketamine Treatment for Mood Disorders. Neuropsychopharmacology 42, 1179-1181.

Sanacora, G., Smith, M. A., Pathak, S., Su, H. L., Boeijinga, P. H., McCarthy, D. J., Quirk, M. C., 2014. Lanicemine: a low-trapping NMDA channel blocker produces sustained antidepressant efficacy with minimal psychotomimetic adverse effects. Mol Psychiatry 19, 978-985.

Sanacora, G., Treccani, G., Popoli, M., 2012. Towards a glutamate hypothesis of depression: an emerging frontier of neuropsychopharmacology for mood disorders. Neuropharmacology 62, 63-77.

Santana, N., Troyano-Rodriguez, E., Mengod, G., Celada, P., Artigas, F., 2011. Activation of thalamocortical networks by the N-methyl-D-aspartate receptor antagonist phencyclidine: reversal by clozapine. Biol Psychiatry 69, 918-927.

Shaffer, C. L., Osgood, S. M., Smith, D. L., Liu, J., Trapa, P. E., 2014. Enhancing ketamine translational pharmacology via receptor occupancy normalization. Neuropharmacology 86, 174-180.

Singh, J. B., Fedgchin, M., Daly, E. J., De Boer, P., Cooper, K., Lim, P., Pinter, C., Murrough, J. W., Sanacora, G., Shelton, R. C., Kurian, B., Winokur, A., Fava, M., Manji, H., Drevets, W. C., Van Nueten, L., 2016. A Double-Blind, Randomized, Placebo-Controlled, Dose-Frequency Study of Intravenous Ketamine in Patients With Treatment-Resistant Depression. Am J Psychiatry 173, 816-826.

Sittig, N., Davidowa, H., 2001. Histamine reduces firing and bursting of anterior and intralaminar thalamic neurons and activates striatal cells in anesthetized rats. Behav Brain Res 124, 137-143.

Skolnick, P., Layer, R. T., Popik, P., Nowak, G., Paul, I. A., Trullas, R., 1996. Adaptation of N-methyl-Daspartate (NMDA) receptors following antidepressant treatment: implications for the pharmacotherapy of depression. Pharmacopsychiatry 29, 23-26.

Skolnick, P., Popik, P., Trullas, R., 2009. Glutamate-based antidepressants: 20 years on. Trends Pharmacol Sci 30, 563-569. 
Stahl, S. M., 2000. Placebo-controlled comparison of the selective serotonin reuptake inhibitors citalopram and sertraline. Biol Psychiatry 48, 894-901.

Steriade, M., McCormick, D. A., Sejnowski, T. J., 1993. Thalamocortical oscillations in the sleeping and aroused brain. Science 262, 679.

Suzuki, K., Nosyreva, E., Hunt, K. W., Kavalali, E. T., Monteggia, L. M., 2017. Effects of a ketamine metabolite on synaptic NMDAR function. Nature 546, E1-E3.

Timofeev, I., Chauvette, S., 2011. Thalamocortical oscillations: local control of EEG slow waves. Curr Top Med Chem 11, 2457-2471.

Trivedi, M. H., Rush, A. J., Wisniewski, S. R., Nierenberg, A. A., Warden, D., Ritz, L., Norquist, G., Howland, R. H., Lebowitz, B., McGrath, P. J., Shores-Wilson, K., Biggs, M. M., Balasubramani, G. K., Fava, M., 2006. Evaluation of outcomes with citalopram for depression using measurement-based care in STAR*D: implications for clinical practice. Am J Psychiatry 163, 28-40.

Troyano-Rodriguez, E., Llado-Pelfort, L., Santana, N., Teruel-Marti, V., Celada, P., Artigas, F., 2014. Phencyclidine inhibits the activity of thalamic reticular gamma-aminobutyric acidergic neurons in rat brain. Biol Psychiatry 76, 937-945.

Ushimaru, M., Ueta, Y., Kawaguchi, Y., 2012. Differentiated participation of thalamocortical subnetworks in slow/spindle waves and desynchronization. J Neurosci 32, 1730-1746.

Vollenweider, F. X., Kometer, M., 2010. The neurobiology of psychedelic drugs: implications for the treatment of mood disorders. Nat Rev Neurosci 11, 642-651.

Wenzel, A., Fritschy, J. M., Mohler, H., Benke, D., 1997. NMDA receptor heterogeneity during postnatal development of the rat brain: differential expression of the NR2A, NR2B, and NR2C subunit proteins. J Neurochem 68, 469-478.

Whittington, M. A., Traub, R. D., Kopell, N., Ermentrout, B., Buhl, E. H., 2000. Inhibition-based rhythms: experimental and mathematical observations on network dynamics. Int J Psychophysiol 38, 315-336.

Wood, J., Kim, Y., Moghaddam, B., 2012. Disruption of prefrontal cortex large scale neuronal activity by different classes of psychotomimetic drugs. J Neurosci 32, 3022-3031.

Yamakura, T., Mori, H., Masaki, H., Shimoji, K., Mishina, M., 1993. Different sensitivities of NMDA receptor channel subtypes to non-competitive antagonists. Neuroreport 4, 687-690.

Yen, C.-T., Shaw, F.-Z., 2003. Reticular thalamic responses to nociceptive inputs in anesthetized rats. Brain Res 968, 179-191.

Zanos, P., Moaddel, R., Morris, P. J., Georgiou, P., Fischell, J., Elmer, G. I., Alkondon, M., Yuan, P., Pribut, H. J., Singh, N. S., Dossou, K. S., Fang, Y., Huang, X. P., Mayo, C. L., Wainer, I. W., Albuquerque, E. X., Thompson, S. M., Thomas, C. J., Zarate, C. A., Jr., Gould, T. D., 2016. NMDAR inhibition-independent antidepressant actions of ketamine metabolites. Nature 533, 481-486. 
Zarate, C. A., Jr., Singh, J. B., Carlson, P. J., Brutsche, N. E., Ameli, R., Luckenbaugh, D. A., Charney, D. S., Manji, H. K., 2006. A randomized trial of an N-methyl-D-aspartate antagonist in treatment-resistant major depression. Arch Gen Psychiatry 63, 856-864.

Zhang, Y., Llinas, R. R., Lisman, J. E., 2009. Inhibition of NMDARs in the Nucleus Reticularis of the Thalamus Produces Delta Frequency Bursting. Front Neural Circuits 3, 20. 


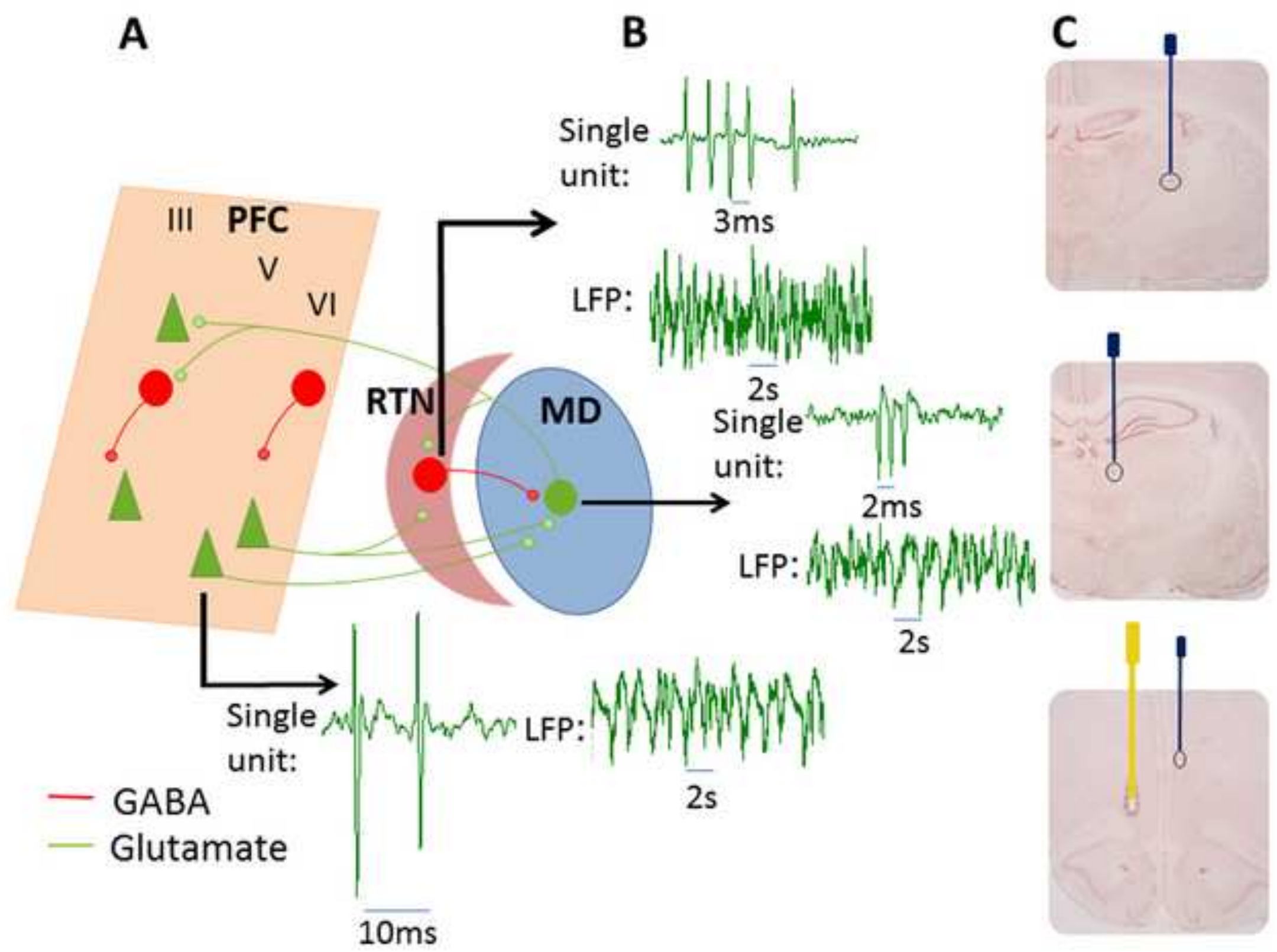


Figure 2

Click here to download high resolution image

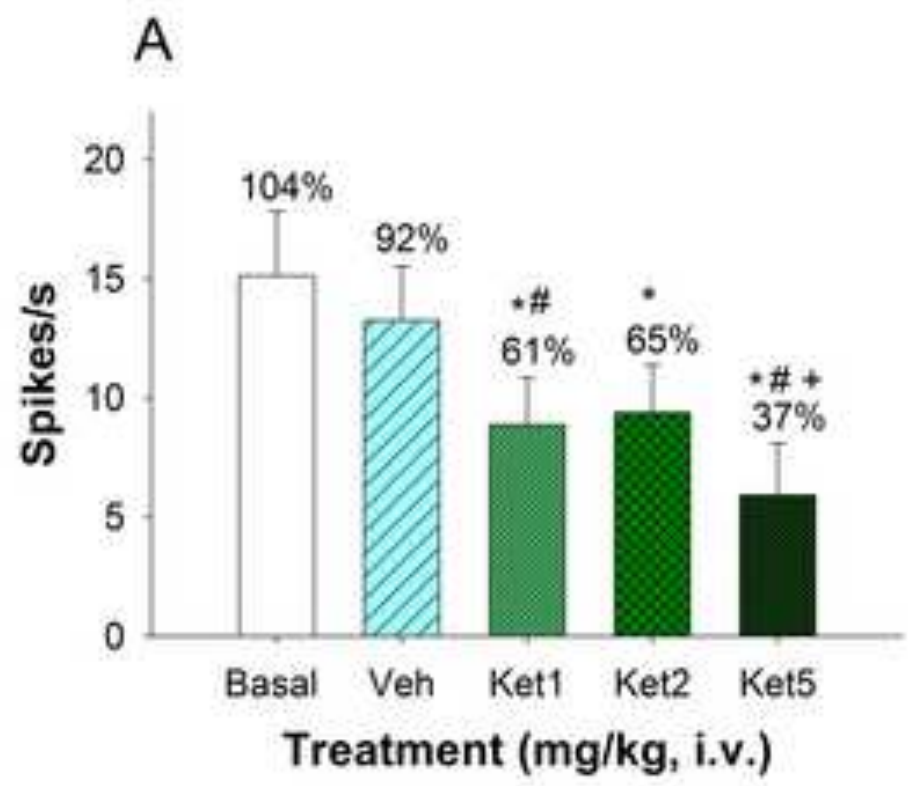

B
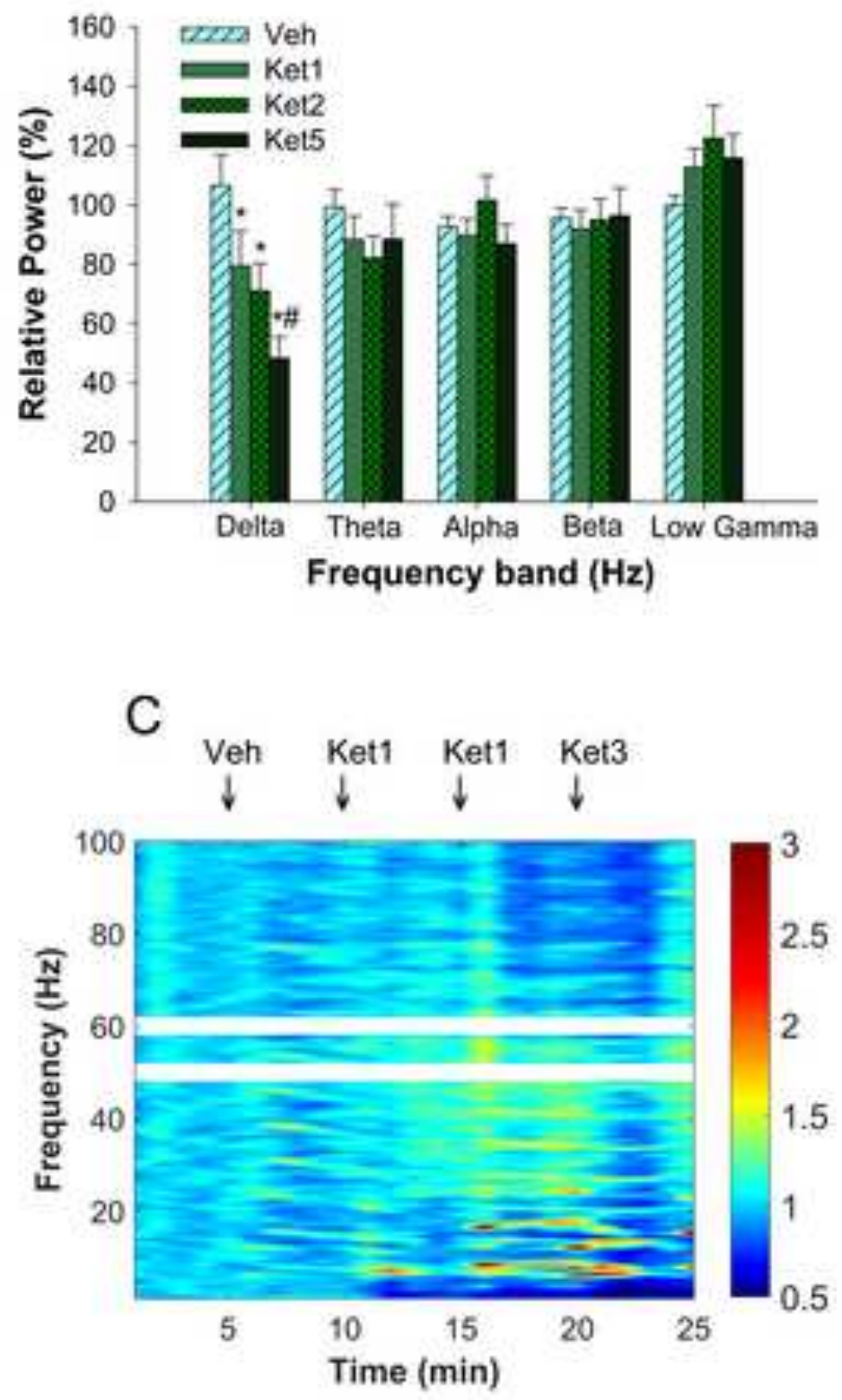
A

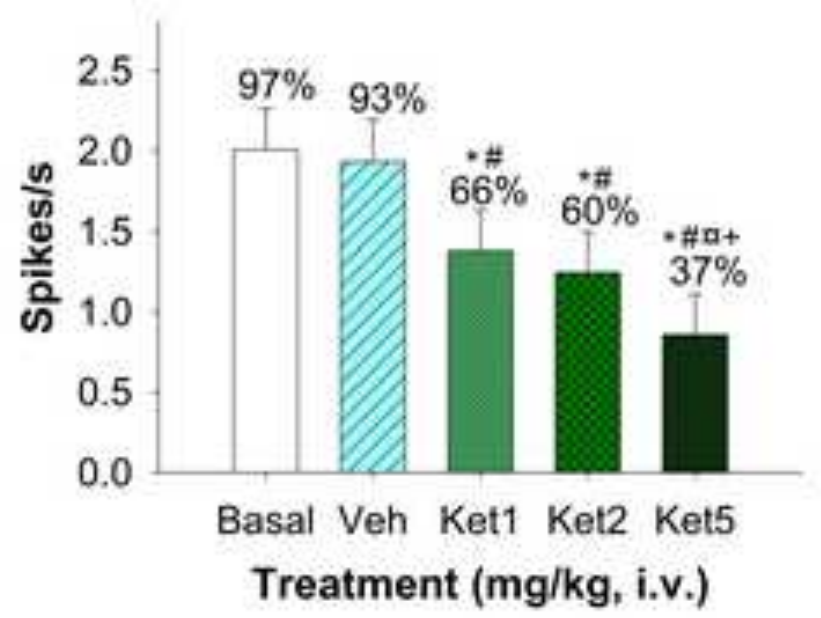

D

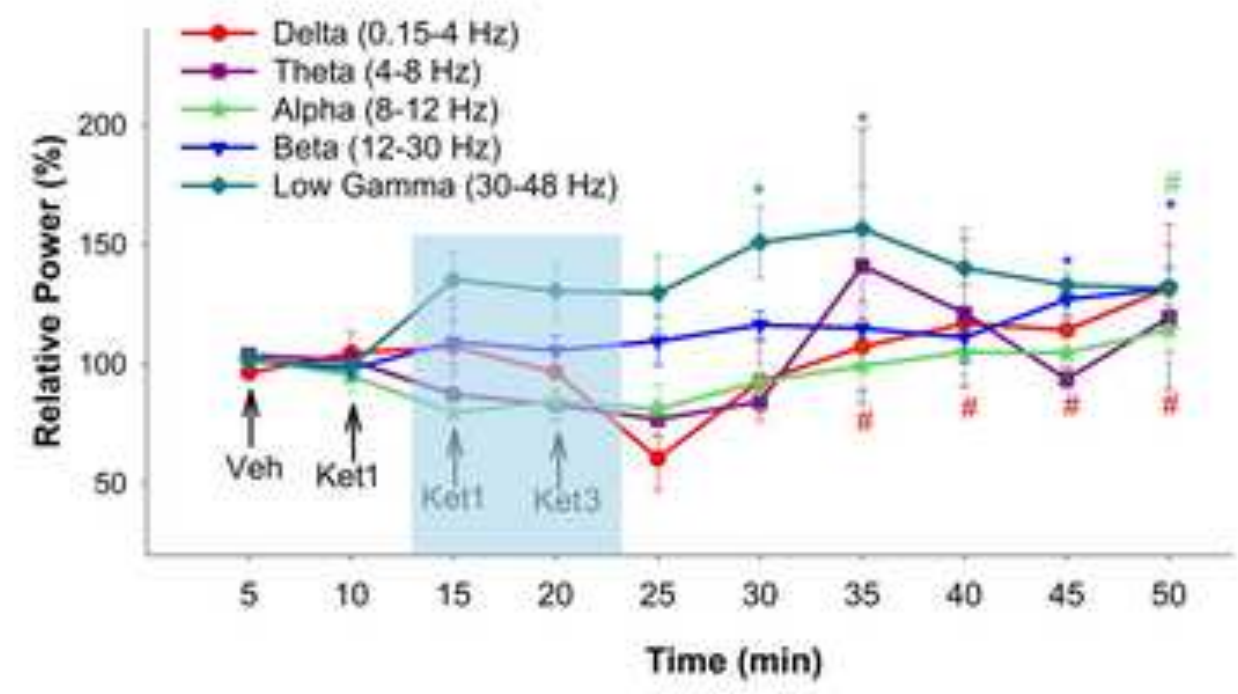

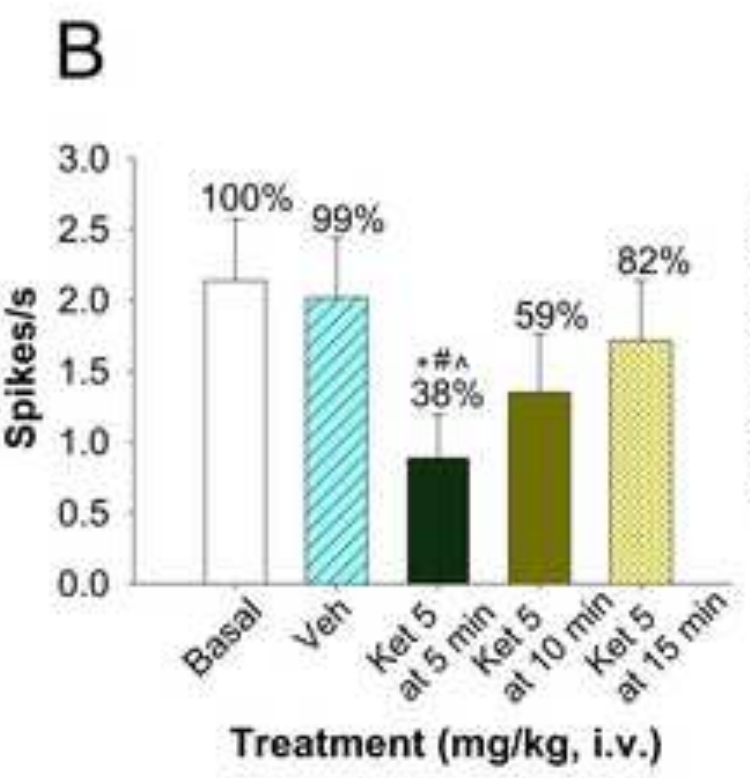

C

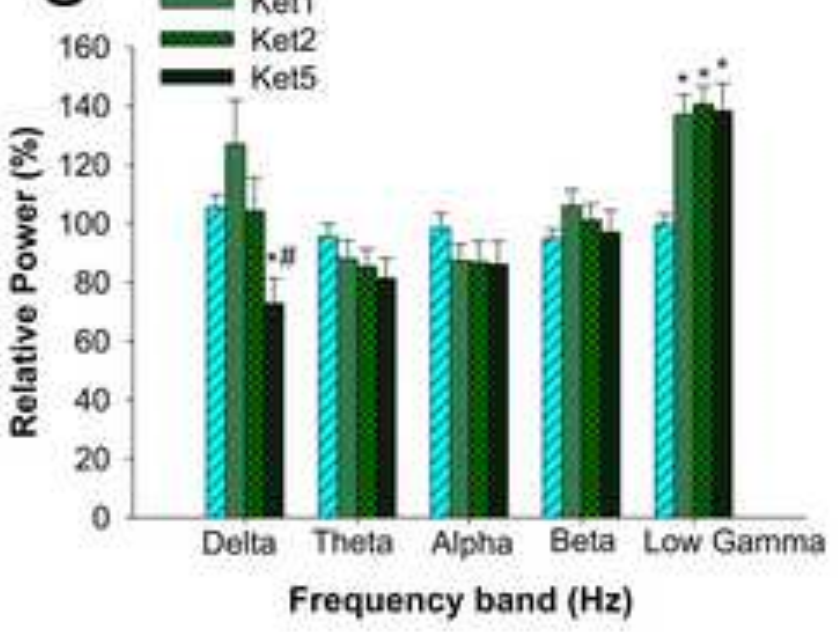

E veh Ket1Ket1Ket3

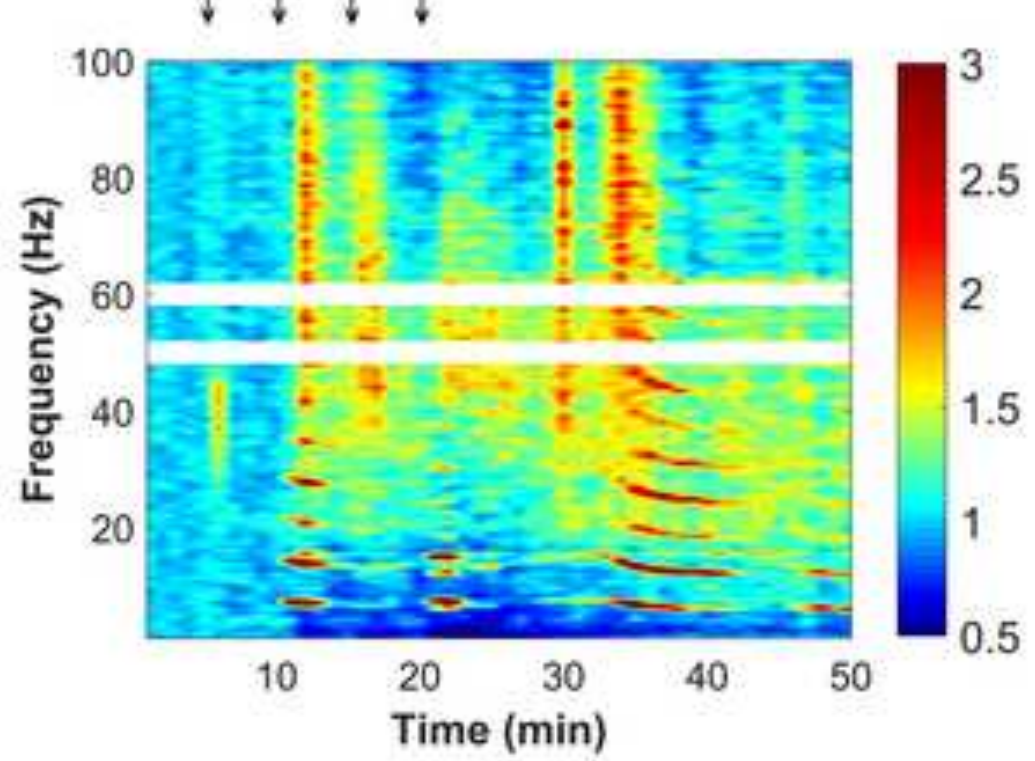

\section{5}

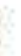


A

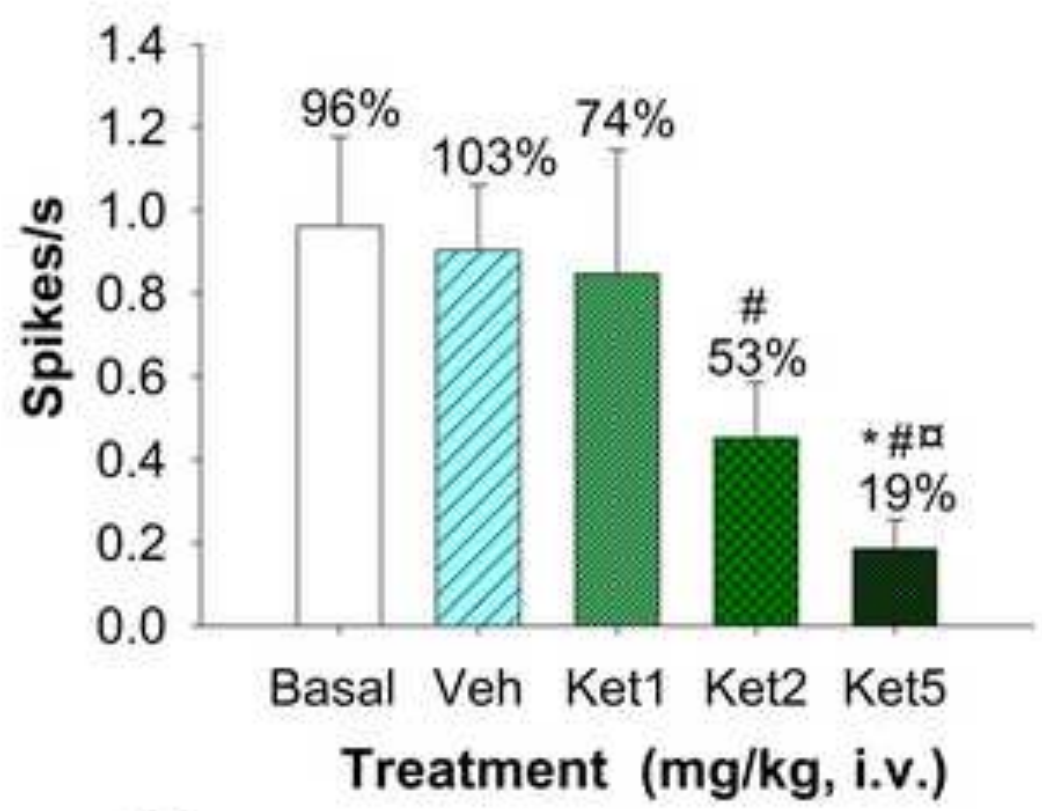

C

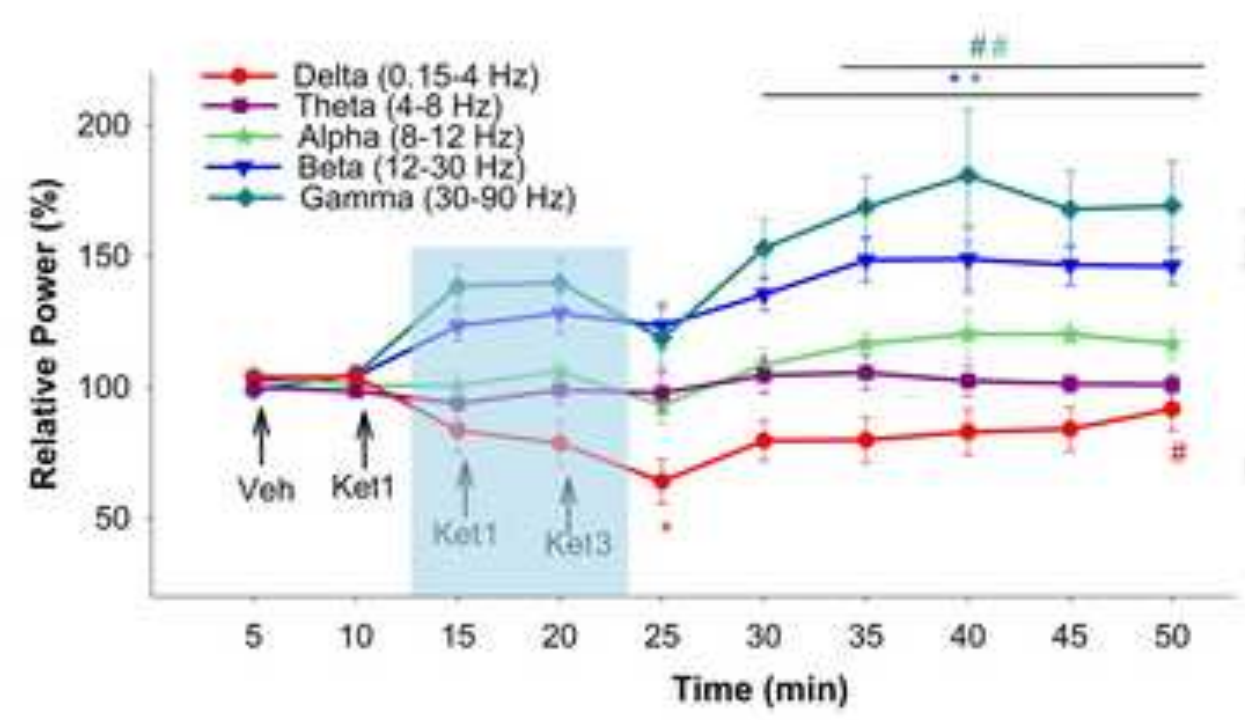

B

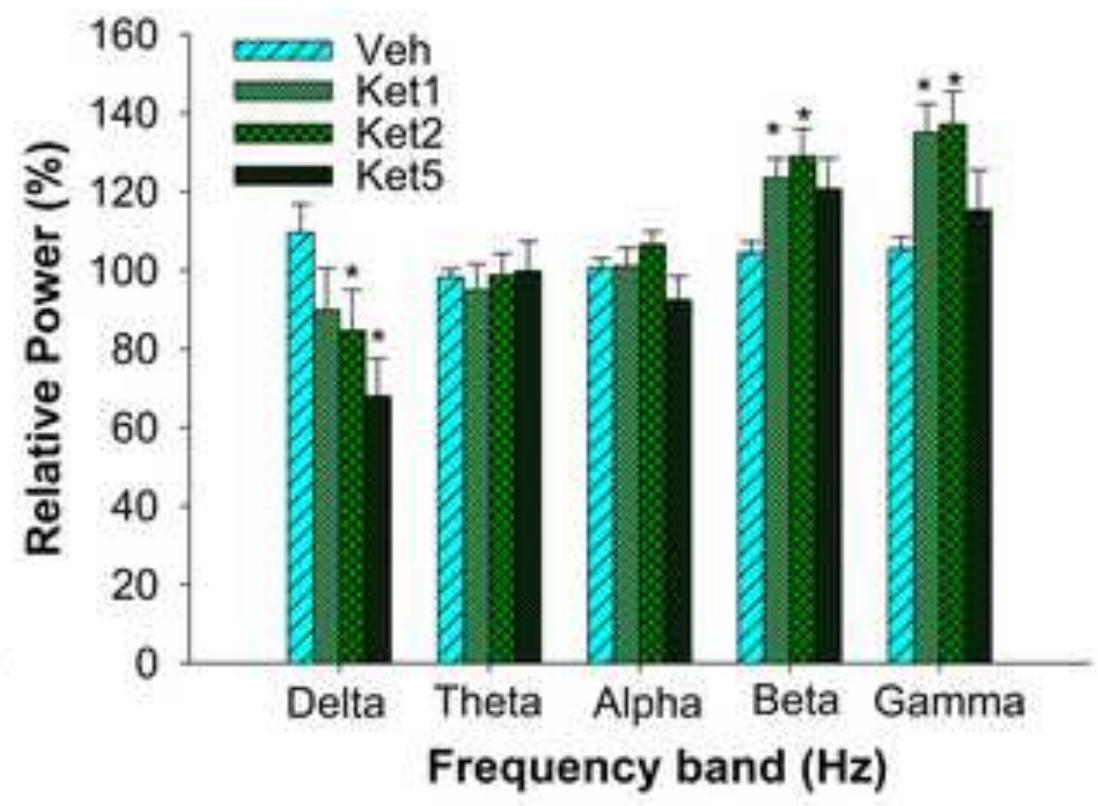

D

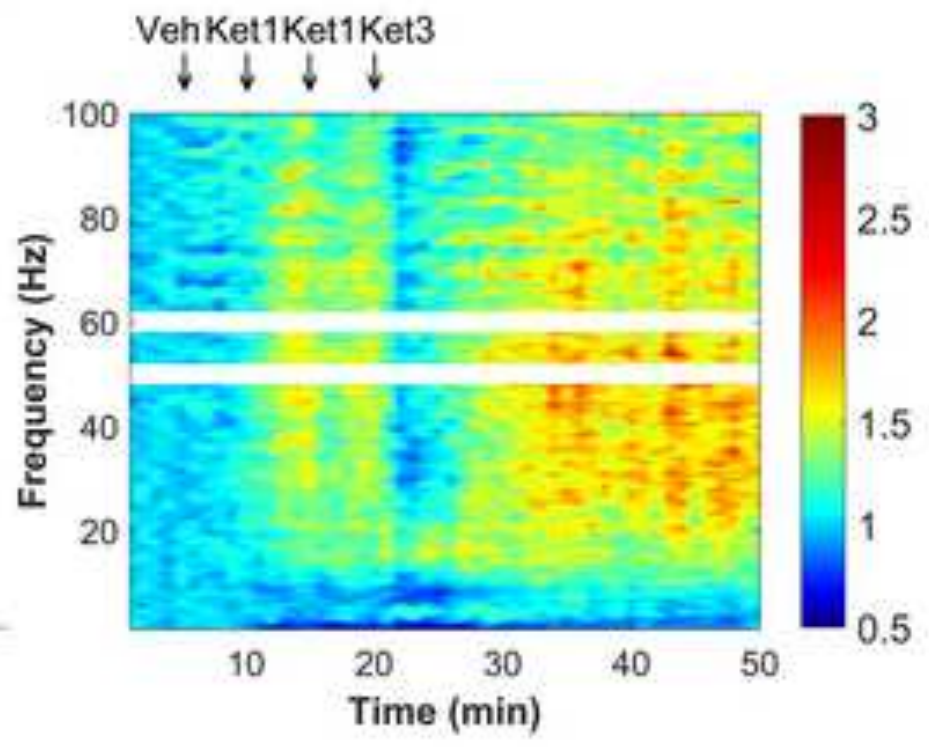




\section{Thalamus}

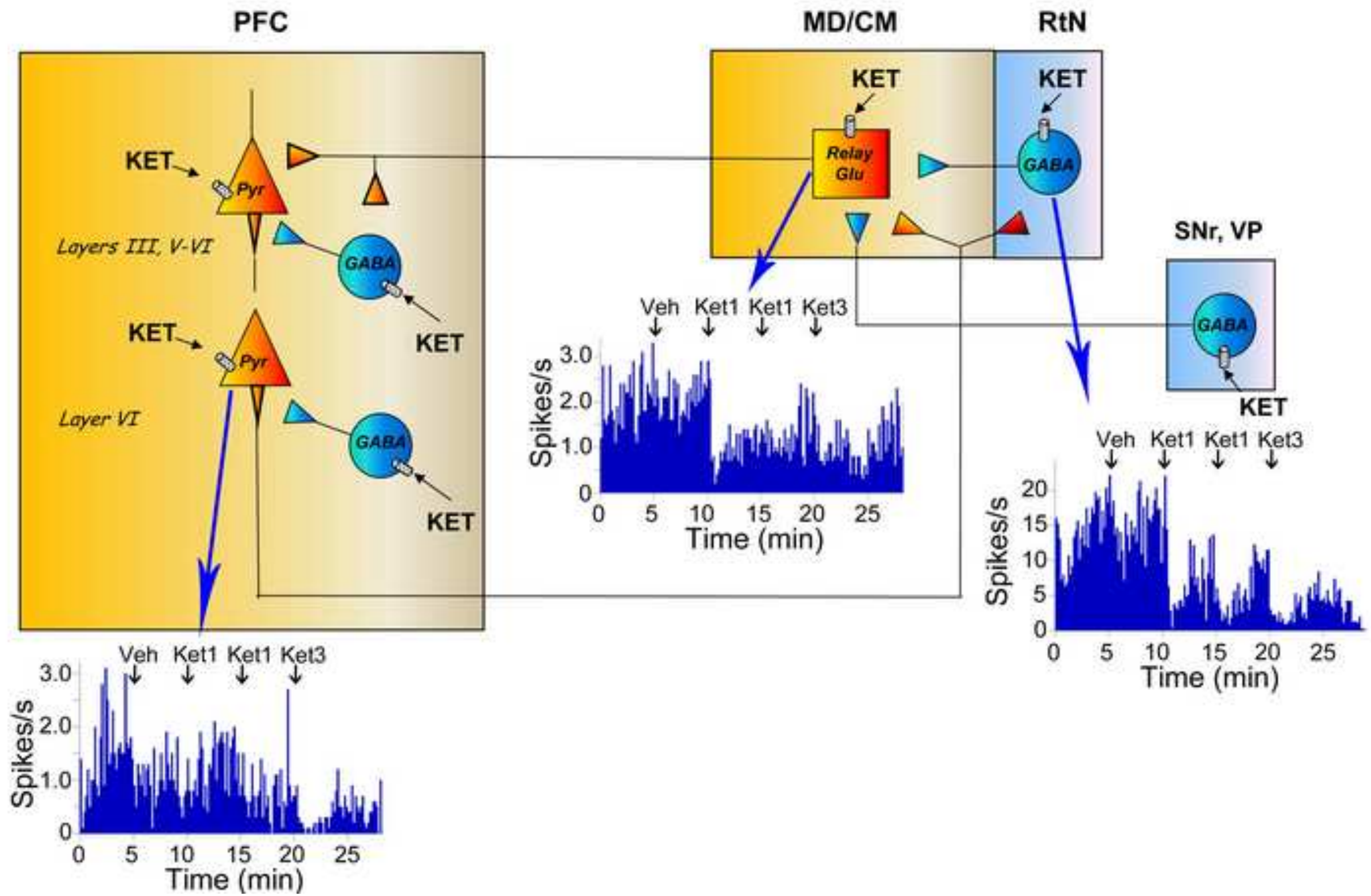

